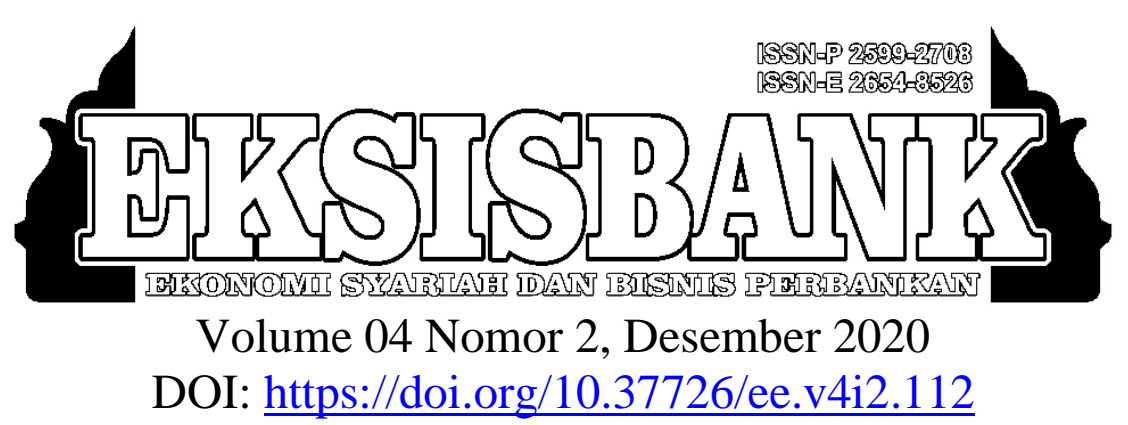

\title{
Implementasi Pembiayaan Ultra Mikro Berdasarkan Prinsip Syariah di KSPPS BMT Purwakarta Amanah Sejahtera (PAS)
}

\author{
Sandi Jaelani ${ }^{1}$, Imam Sucipto ${ }^{2}$, Jalaludin ${ }^{3}$ \\ ${ }^{1,2,3}$ Sekolah Tinggi Ilmu Ekonomi Syariah (STIES) Indonesia Purwakarta \\ ${ }^{1}$ sandijaelani63@gmail.com \\ 2imamsucipto@gmail.com \\ 3 jalaludin@sties-purwakarta.ac.id
}

\begin{abstract}
ABSTRAK
Tingkat kebutuhan masyarakat di Indonesia dari tahun ke tahun meningkat. Hal ini memaksa masyarakat untuk membuka suatu usaha atau berwirausaha. Untuk memulainya, masyarakat membutuhkan pembiayaan untuk modal usaha. Tetapi tidak semua pembiayaan dapat dilayani oleh perbankan. Sehingga hal ini menyulitkan para pelaku usaha kecil yang berada dilapisan bawah. Kondisi tersebut mendorong pemerintah melalui menteri keuangan mengelurakan Peraturan Menteri Keuangan (PMK) nomor 22/05/2017 tentang Pembiayaan Ultra Mikro. Dimana Pembiayaan Ultra Mikro ini dapat dilakukan oleh lembaga non bank, salah satunya koperasi Syariah. Tujuan dari penelitian ini adalah untuk mengetahui model pembiayaan ultra mikro yang ada di KSPPS BMT Purwakarta Amanah Sejahtera (PAS), dan bagaimana implementasi pembiayaan ultra mikro di KSPPS BMT Purwakarta Amanah Sejahtera (PAS). Jenis penelitian yang digunakan adalah penelitian lapangan (field research), adapun pendekatan yang digunakan dalam penelitian ini adalah pendekatan deskriptif-kualitatif. Pembiayaan ultra mikro yang dilakukan di KSPPS BMT PAS terdapat dua jenis yaitu pembiayaan ultra mikro multibarang dan pembiayaan ultra mikro multijasa untuk pembiayaan ultra mikro multibarang menggunakan akad Murabahah dan pelaksanaannya sesuai dengan fatwa DSN-MUI nomor 04/DSN-MUI/IV/2000 tentang Murabahah. Kemudian untuk pembiayaan ultra mikro multijasa menggunakan akad ijarah dengan bentuk wakalah bil ujrah pelaksanaannya sudah sesuai dengan fatwa DSN-MUI nomor 09/DSN-MUI/IV/2000 tentang pembiayaan ijarah dan fatwa DSN-MUI nomor 112/DSN-MUI/IX/2017 tentang akad ijarah. Sehingga dalam pelaksanaan pembiayaan ultra mikro di KSPPS BMT PAS sudah sesuai dengan fatwa DSN-MUI nomor 119/DSN-MUI/II/2918 tentang pembiayaan ultra mikro berdasarkan prinsif syariah.
\end{abstract}

Kata Kunci: Pembiayaan Ultra Mikro, Ijarah, Murabahah, KSPPS BMT PAS.

EKSISBANK (Ekonomi Syariah dan Bisnis Perbankan), Volume 4, Nomor 2, Desember 2020 http://journal.sties-purwakarta.ac.id/index.php/EKSISBANK/

ISSN: 2654-8526 (Media Online) 2599-2708 (Media Cetak) 


\begin{abstract}
The level of community demand in Indonesia increases from year to year. This forces people to open a business or become an entrepreneur. To begin with, people need financing for business capital. But not all financing can be served by banks. So this makes it difficult for small business actors who are on the lower layers. This condition prompted the government through the finance minister to issue the Minister of Finance Regulation (PMK) number 22/05/2017 concerning Ultra Micro Financing. Where this Ultra Micro Financing can be carried out by non-bank institutions, one of which is a Sharia cooperative. The purpose of this study was to determine the ultra-micro financing model in KSPPS BMT Purwakarta Amanah Sejahtera (PAS), and how to implement ultra-micro financing at KSPPS BMT Purwakarta Amanah Sejahtera (PAS). This type of research is field research (field research), while the approach used in this research is a descriptive-qualitative approach. There are two types of ultra-micro financing carried out at KSPPS BMT PAS, namely multi-goods ultra-micro financing and multi-service ultra-micro financing for multi-goods ultra-micro financing using the Murabahah contract and its implementation is in accordance with the DSN-MUI fatwa number 04 / DSN-MUI / IV / 2000 concerning Murabahah. . Then for multi-service ultra micro financing using the ijarah contract in the form of wakalah bil ujrah the implementation is in accordance with the DSN-MUI fatwa number 09 / DSN-MUI / IV / 2000 regarding ijarah financing and the DSN-MUI fatwa number 112 / DSN-MUI / IX / 2017 about the ijarah contract. So that the implementation of ultra-micro financing at KSPPS BMT PAS is in accordance with the DSN-MUI fatwa number 119 / DSN-MUI / II / 2918 concerning ultramicro financing based on sharia principles.
\end{abstract}

Key words: Ultra Micro Financing, Ijarah, Murabahah, KSPPS BMT PAS

\section{PENDAHULUAN}

Tingkat kebutuhan masyarakat di Indonesia dari tahun ke tahun semakin meningkat. Kemiskinan, pengangguran, dan akses permodalan bagi pelaku Usaha Mikro, Kecil dan Menengah (UMKM) masih menjadi persoalan yang belum selesai di Negeri ini. Berdasarkan data Otoritas Jasa Keuangan atau OJK data inklusi keuangan di Indonesia pada tahun 2013 sudah mencapai $59,74 \%$, pada tahun 2016 naik menjadi $67,82 \%$, dan pada tahun 2019 kemaren meningkat menjadi 76,19\%. (Haliding, 2019). Grafik 1.1

Indeks Inklusi Keuangan Indonesia Pada 2016-2019

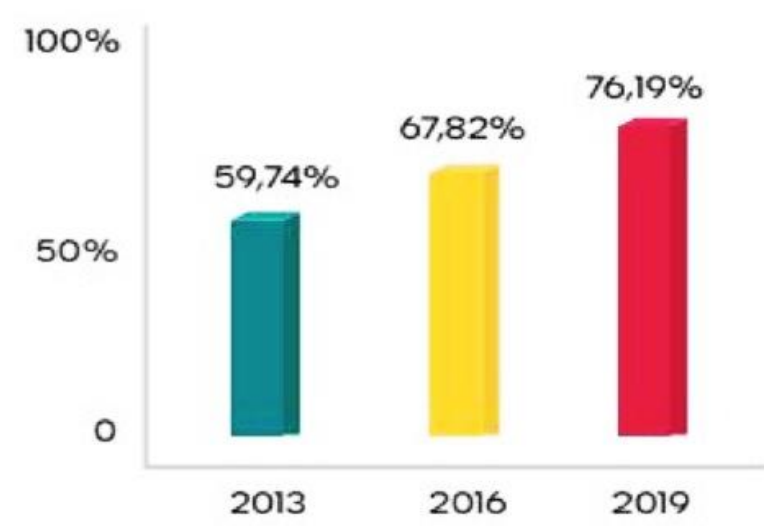

Sumber : Survey OJK 2019

Dalam setiap memenuhi kebutuhannya, manusia harus melakukan kegiatan ekonomi. Menurut Winardi, manusia adalah makhluk ekonomi (homo economicus), yaitu dalam melakukan tindakan ekonominya, manusia didorong oleh kepentingan sendiri dan bertindak berdasarkan prinsip ekonomi (Yuniarti, 2016). Oleh karena itu, salah satu

EKSISBANK (Ekonomi Syariah dan Bisnis Perbankan), Volume 4, Nomor 2, Desember 2020 http://journal.sties-purwakarta.ac.id/index.php/EKSISBANK/ 
yang dapat dilakukan untuk memenuhi kebutuhan tersebut yaitu dengan cara membuka usaha atau berwirausaha. Dalam proses membuka suatu usaha atau berwirausaha yang paling utama adalah modal usaha, untuk mendapatkan modal usaha tersebut, saat ini banyak lembagalembaga perbankan ataupun non bank yang menyediakan produk pinjaman atau pembiayaan untuk modal usaha.

Namun, pada pelaksanaannya untuk lembaga perbankan tidak menerima pembiayaan dengan nominal kecil, rata-rata lembaga perbankan menerima pembiayaan diatas Rp. 10.000.000. Sehingga untuk para pelaku UMKM khususnya pelaku usaha paling kecil atau ultra mikro tidak dapat tersentuh dan terbantu semua oleh lembaga perbankan dalam meningkatkan usahanya. Sedangkan menurut Badan Pusat Statistik, angka dan jumlah kemiskinan pada bulan Maret 2019 masih terbilang cukup tinggi yaitu sebesar 9,41\% atau 25,14 juta orang (Yuniarti, 2016).

Pembiayaan Ultra Mikro atau UMi sendiri dapat dilakukan secara umum dan syariah. Pada koperasi umum dan koperasi syariah terdapat beberapa perbedaan, dikarenakan ada beberapa persyaratan yang berbeda salah satunya yaitu pada lembaga koperasi syariah menggunakan prinsip-prinsip syariah sedangkan koperasi umum tidak menggunakan prinsip syariah.

Dalam pembiayaan UMi pada koperasi syari'ah atau yang sering disebut Baitul Maal Wa Tamwil (BMT) telah diatur dalam Fatwa DSN-MUI yaitu Fatwa No 119/DSNMUI/II/2018 tentang pembiayaan ultra mikro. Pada pelaksanaannya pembiayaan UMi harus sesuai dengan prinsip-prinsip syariah salah satunya tidak adanya pihak yang mendzalimi dan di dzalimi, seperti dijelaskan dalam AlQuran Surat An-Nisa ayat 29.

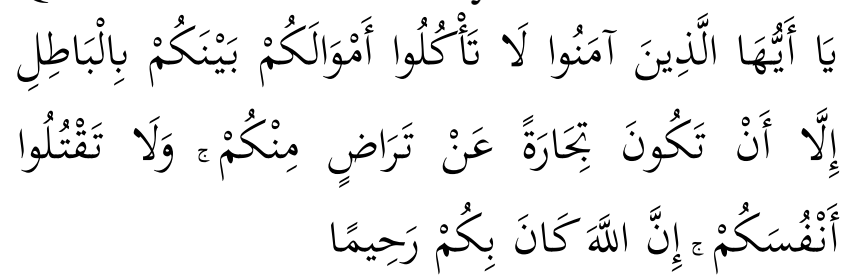

"Hai orang-orang yang beriman! Janganlah kalian memakan (mengambil) harta arang lain secara batil, kecuali jika berupa perdagangan yang dilandasi atas sukarela di antara kalian...." (Enang, 2010)

Ayat ini menerangkan hukum transaksi secara umum, lebih khusus kepada transaksi perdagangan, bisnis jual beli. Sebelumnya telah diterangkan transaksi muamalah yang berhubungan dengan harta, seperti harta anak yatim, mahar, dan sebagainya. Dalam ayat ini Allah mengharamkan orang beriman untuk memakan, memanfaatkan, menggunakan, dan (segala bentuk transaksi lainnya) harta orang lain dengan jalan yang batil, yaitu yang tidak dibenarkan oleh syari'at. Kita boleh melakukan transaksi terhadap harta orang lain dengan jalan perdagangan dengan asas saling ridha, saling ikhlas. Dan dalam ayat ini Allah juga melarang untuk bunuh diri, baik membunuh diri sendiri maupun saling membunuh. Dan Allah menerangkan semua ini, sebagai wujud dari kasih sayang-Nya, karena Allah itu Maha Kasih Sayang kepada kita (M-Kita, 2019).

Dalam usaha untuk mengurangi angka kemiskinan pemerintah mengeluarkan beberapa program untuk memajukan para pelaku atau kelompok UMKM, salah satunya adalah program Kredit Usaha Rakyat (KUR). Namun pada pelaksanaannya KUR ini masih banyak kendala dan belum bisa efektif untuk menyentuh semua usaha mikro terutama dilapisan paling bawah (ultra atau supermikro). Karena masih banyak pelaku UMKM yang belum bisa akses ke 
pembiayaan perbankan karena persyaratan perbankan terlalu ketat, terutama harus adanya jaminan.

Dalam penyaluran nya UMi dilakukan melalui kerja sama Pusat Investasi Pemerintah (PIP) dengan tiga penyalur yang telah ditunjuk yaitu PT. Pegadaian, PT Permodalan Nasional Madani (PNM), dan PT Bahana Artha Ventura (BAV). Pada perkembangannya pembiayaan UMi yang dilakukan oleh PT Pegadaian terus dilakukan peningkatan penyaluran pembiayaan UMi dalam upaya membantu perkembangan UMKM yang belum pernah mendapatkan pasilitas kredit dari perbankan (unbankable). Salah satu daerah yang sudah dilakukan penyaluran oleh PT Pegadaian adalah daerah Gorontalo mencapai Rp 1.898 miliar untuk 273 debitur (Pegadaian, 2019).

Lembaga keuangan pada umumnya melakukan kegiatan Funding (Pemasukan Dana) dan Lending (Pengeluaran Dana), termasuk pada Koperasi Simpan Pinjam Pembiayaan Syariah (KSPPS) BMT Purwakarta Amanah Sejahtera (PAS). Pada KSPPS BMT PAS melakukan kegiatan Funding (pemasukan) dan Lending (pengeluaran/pembiayaan).

Dalam kegiatan pembiayaan KSPPS BMT PAS melakukan pembiayaan Ultra Mikro, dimana pembiayaan Ultra Mikro sendiri terdapat beberapa jenis akad. Yang mana dalam setiap akadnya tentu memiliki aturan dan syarat yang berbeda. Disini penulis melihat dari dua aspek yang akan diperdalam yaitu, model, dan implementasi. Dalam hal model, penulis akan melihat model akad apa saja yang digunakan oleh KSPPS BMT PAS. Kemudian, dalam implementasi atau pelaksanaan setiap akad syarat dan rukunnya harus terpenuhi sesuai dengan aturan hukum yang telah ditetapkan dalam fatwa DSN-MUI. Dari ketiga aspek tersebut dapat dilihat apakah di KSPPS BMT PAS dalam pelaksanaan akad Ultra Mikro sudah sesuai dengan prinsip-prinsip syariah atau tidak sesuai. Maka dapat diketahui dan dapat disimpulkan diakhir setelah penulis melakukan penelitian di KSPPS BMT PAS.

Dampak yang diberikan dalam pembiayaan ultra mikro tentunya akan mempengaruhi perkembangan di KSPPS BMT PAS sendiri. Pembiayaan Ultra Mikro telah diatur dalam Fatwa Nomor 119/DSNMUI/II/2018 tentang pembiayaan ultra mikro berdasarkan prinsip syariah. Maka dalam pelaksanan nya harus sesuai dengan prinsipprinsip syariah yang telah ditetapkan oleh fatwa DSN-MUI.

Adapun maksud dan tujuan dari penelitian ini adalah untuk mengetahui model pemniayaan ultra mikro yang ada di KSPPS BMT Purwakarta Amanah Sejahtera (PAS), dan untuk mengetahui implementasi pembiayaan ultra mikro yang ada di KSPPS BMT Purwakarta Amanah Sejahtera (PAS).

\section{TINJAUAN PUSTAKA}

Penelitian tentang Implementasi Pembiayaan Ultra Mikro Berdasarkan Prinsip Syariah sudah banyak dilakukan oleh peneliti sebelumnya, tapi tentu saja mempunyai perbedaan-perbedaan antara penelitian ini dengan penelitian sebelumnya. Berikut adalah penelitian sebelumnya yang meneliti tentang Implementasi Pembiayaan Ultra Mikro Berdasarkan Prinsip Syariah di KSPPS BMT Purwakarta Amanah Sejahtera (PAS);

1. Penerapan Implementasi Penerapan Pembiayaan Ultra Mikro di BMT-UGT Sidogiri (Muttaqin \& Hartono, 2019)

Lembaga keuangan berfungsi sebagai lembaga intermediasi yaitu menghubungkan antara surplus unit dengan deficit unit. Namun masih banyak usaha mikro yang kesulitan mendapatkan bantuan permodalan dari lembaga keuangan (perbankan). Para 
pelaku usaha mikro yang kesulitan mendapatkan kredit dari bank tersebut mencari lembaga keuangan non formal yang mudah diakses untuk mengajukan kredit seperti rentenir. Dibalik kemudahan yang diberikan rentenir, terdapat hal yang dirasa memberatkan para pelaku usaha karena harus menanggungg bunga sebesar 10\%-30\% setiap bulan dan denda jika mengalami keterlambatan. Kementrian Keuangan mempunyai program yang dapat dijadikan solusi untuk menyediakan fasilitas pembiayaan yang mudah dan cepat bagi usaha mikro yaitu pembiayaan ultra mikro (UMI). BMT-UGT Sidogiri merupakan lembaga linkage dibawah naungan PT. Bahana Artha Ventura yang menyalurkan pembiayaan ultra mikro kepada anggota UMI. Oleh karena itu, penelitian ini bertujuan untuk mengetahui penerapan pembiayaan ultra mikro di BMT-UGT Sidogiri dalam membantu permodalan usaha mikro. Penelitian ini menggunakan analisis deskriptif dengan wawancara dan studi literature sebagai metode pengambilan data. Informan kunci pada penelitian ini yaitu ketua divisi pembiayaan BMT-UGT Sidogiri Pusat, kepala kantor layanan BMT-UGT Sidogiri, dan anggota UMi. Sedangkan didukung oleh studi literature terkait pembiayaan UMI yang diperoleh dari Kementrian Keuangan dan Kementrian Koperasi dan UMKM.

2. Tinjauan Hukum Islam Terhadap Bantuan

Modal Usaha Super Mikro Kerjasama Antara Baznas Kabupaten Bojonegoro Dengan Bank Perkreditan Rakyat (BPR) Bojonegoro Dengan Sistem Qard Al Hasan (Cahyono, 2019)

Badan Amil Zakat Nasional (BAZNAS) Kabupaten Bojonegoro bekerjasama dengan PD Bank Perkreditan Rakyat (BPR) Bojonegoro memberikan bantuan modal usaha melalui pembiayaan usaha super mikro dengan prinsip syariah kepada masyarakat dari keluarga tidak mampu yang memiliki usaha kecil dan aktif menjadi jamaah Masjid. Dalam hal ini BPR mengambil keuntungan dari jumlah pembiayaan yang dibebankan kepada BAZNAS Kab. Bojonegoro dengan mengatasnamakan uang pendampingan dan administrasi, sehingga nasabah hanya membayar angsuran setiap bulannya. Berdasarkan hal tersebut pembiayaan yang dilakukan oleh BPR kerjasama dengan Baznas Kab. Bojonegoro terdapat unsur riba dan hilah. Indikasi riba karena BPR mengambil keuntungan dari pembiayaan yang berakad Qard Al-Hasan, sedangkan indikasi hilah karena BAZNAS menyalurkan dana ke Lembaga Konvensional. Dari Hasil Penelitian diketahui bahwa Baznas Kab. Bojonegoro bersegmentasi pada non profit (Tabarru') atau memberikan bantuan kepada Mustahiq yang mempunyai usaha kecil dengan membayar uang administrasi $1 \%$ dan uang pendampingan $6 \%$ kepada BPR atas pembiayaan yang dilakukan oleh mustahiq. Dana yang diberikan Baznas Kabupaten Bojonegoro kepada BPR berasal dari dana Infak dan shodaqoh. Saran dari penulis adalah program Bantuan Modal Usaha melalui pembiayaan super mikro ini diharapakan terus berjalan dan dikembangkan, dan dalam kerjasama Baznas Kabupaten Bojonegoro diharapkan untuk memilih Lembaga Keuangan Syariah bukan konvensional agar pengimplementasian teori akad maupun hukum islam lebih tepat dan sesuai dengan prinsip syariah.

3. Pembiayaan Ultra Mikro Dalam Peraturan Menteri Keuangan No 95/PMK.05/2018 dan Fatwa Dewan Syariah Nasional No 119/DSN-MUI/II/2018 (Surnida, 2020) 
Pembiayaan Ultra Mikro hadir sebagai solusi bagi masyarakat dari lapisan terbawah yang membutuhkan dana pinjaman. Pembiayaan ini diatur oleh peraturan Menteri Keuangan No 95/PMK.05/ 2018 dan juga diatur dalam Fatwa Dewan Syariah Nasional No.119/DSN-MUI/II/2018. Namun terdapat beberapa perbedaan dalam kedua peraturan tersebut. Kesimpulan yang diperoleh dari penelitian ini adalah Lembaga penyalur pembiayaan ultra mikro menurut Permenkeu NO 95/ PMK.05/2018 adalah lembaga keuangan bukan bank sedangkan menurut Fatwa DSN MUI No 119/DSN-MUI/II/2018 lembaga penyalurnya adalah lembaga keuangan syariah. Sumber pendanaan pembiayaan ultra mikro menurut Permenkeu NO 95/ PMK.05/2018 salah satunya adalah bunga sedangkan dalam fatwa DSN MUI bahwa praktek pembungaan adalah haram. Penetapan margin dalam pembiayaan ultra mikro menurut Permenkeu adalah PIP dapat mengenakan suku bunga/margin kepada penyalur dengan bunga 2\%-4\% sedangkan dalam fatwa DSN MUI No 119/DSNMUI/II/2018 adalah menggunakan konsep bagi hasil dan sesuai dengan akad yang telah ditetapkan. Penyelesaian sengketa pada pembiayaan ultra mikro menurut Permenkeu NO 95/ PMK.05/2018 adalah dengan mekanisme tanggung renteng. Sedangkan dalam fatwa DSN MUI No 119/DSNMUI/II/2018 penyelesaian sengketa dilakukan melalui lembaga penyelesaian sengketa berdasarkan Syariah.

\section{Alternative Sistem Pengawasan Pada} Koperasi Simpan Pinjam Dan Pembiayaan Syariah (KSPPS) Dalam Mewujudkan Shariah Compliance (Hidayat, 2016)

Terdapat dua jenis lembaga keuangan yaitu bank dan non bank yang beroperasi dengan sistem syariah dan konvensional. Koperasi Simpan Pinjam dan Pembiayaan Syariah (KSPPS) adalah salah satu lembaga keuangan bukan Bank yang beroperasi dengan sistem Syariah. Dalam menjalankan operasinya, Koperasi Simpan Pinjam dan Pembiayaan Syariah (KSPPS) beroperasi sesuai dengan syariah atau tidak. Dalam hal ini, ketetapan Dewan Pengawas Syariah sangat penting untuk memastikan bahwa Koperasi Simpan Pinjam dan Pembiayaan Syariah (KSPPS) telah memenuhi prinsip syariah. Meski memiliki Dewan Pengawas Syariah, namun masih banyak Koperasi Simpan Pinjam dan Pembiayaan Syariah (KSPPS) yang tidak sesuai dengan prinsip syariah. Permasalahan ini disebabkan oleh kelemahan Dewan Pengawas Syariah (DPS) dan Sistem Kerumitan mulai dari rekrutmen hingga pertanggungjawaban Dewan Pengawas Syariah. Oleh karena itu, penulis memikirkan sistem pengawasan alternatif Koperasi Simpan Pinjam dan Pembiayaan Syariah (KSPPS) dalam mewujudkan kepatuhan syariah.

\section{Pengaruh Kinerja Pembiayaan Mikro} Musyarakah dan Mudharabah di Bank Syariah terhadap Sektor Usaha Mikro di Provinsi Jawa Timur (Simanjuntak, 2018)

Penelitian ini ingin mengetahui bagaimana pengaruh dari kinerja pembiayaan mikro Islam dengan akad musyarakah dan mudharabah yang diberikan oleh Bank Umum Syariah (BUS) dan Unit Usaha Syariah (UUS) terhadap sektor usaha mikro dan kesejahteraan di Provinsi Jawa Timur. Penelitian ini ingin mengetahui variabelvariabel kinerja pembiayaan mikro musyarakah dan mudharabah yang memengaruhi secara langsung atau tidak langsung terhadap usaha mikro dan 
kesejahteraan di provinsi tersebut. Model yang digunakan dalam penelitian ini diuji dengan Partial Least Squares (PLS) sebagai alat analisis kuantitatif antar variabel yang dipadukan dengan analisis Tawhidi String Relation (TSR) melalui pendekatan mixed method. Hasil uji hipotesis menunjukkan pengaruh yang signifikan dari kinerja pembiayaan mikro bank Islam dengan akad musyarakah dan mudharabah terhadap usaha mikro dan kesejahteraan di Provinsi Jawa Timur. Penelitian ini juga mengungkap kredit dan pembiayaan untuk UMKM terkonsentrasi di Pulau Jawa. Dalam jangka panjang, hal ini dapat menghambat akses pembiayaan UMKM.

6. Peran Baitul Maal Wat Tamwil (BMT) dalam Mewujudkan Ekonomi Syariah yang Kompetitif (Sudjana \& Rizkison, 2020)

Lembaga keuangan mikro syariah Baitul Maal Wat Tamwil (BMT) sangat cocok untuk mengatasi masalah ekonomi berbasis mikroekonomi. BMT menggunakan prinsip Syariah dan bebas riba yang dilarang dalam Islam. Fungsi lembaga ini sebagai pendukung peningkatan upaya ekonomi pengusaha mikro dan kecil berbasis syariah. Tujuan kegiatan BMT yang memiliki keterkaitan erat dengan bisnis ekonomi syariah, pertama adalah hasil target, kedua pertumbuhan, ketiga keberlanjutan, terakhir berkah. Wirausahawan hendaknya menjaga orientasi keberkahan ini agar menjadi visi usahanya, agar selalu dalam kegiatan usahanya senantiasa di kuasai syariah dan menjadi momok Allah. Keempat poin tersebut menjadi prinsip utama BMT dalam realisasinya di lapangan. Peran BMT dalam penguatan ekonomi adalah peningkatan kesempatan kerja dan penerapan sistem keuangan yang berbasis outcome dalam mewujudkan kesetaraan, kejujuran, dan keadilan. Dengan menerapkan prinsipprinsip syariah dan kekuatan Islam ke dalam kehidupan nyata, maka nilai-nilai spiritual diarahkan untuk mengarahkan dan menggerakkan etika yang dinamis, proaktif, progresif, adil dan bermoral.

\section{Mencari Solusi Pengembangan Lembaga} Keuangan Mikro Syariah Di Indonesia (Rusydiana \& Devi, 2013)

LKMS merupakan lembaga keuangan yang berorientasi pada upaya peningkatan kesejahteraan anggota dan masyarakat. Lahirnya lembaga keuangan mikro syariah di Indonesia merupakan salah satu jawaban melihat perkembangan perbankan syariah yang masih terpusat kepada masyarakat menengah ke atas. Faktanya, LKMS telah tumbuh menjadi alternatif pemulihan kondisi perekonomian di Indonesia, khususnya sebagai partner para pengusaha kecil dalam penyediaan modal. Walaupun tumbuh dengan pesat, namun LKMS masih mengalami banyak kendala dalam pengembangannya. Masih banyak permasalahan yang dihadapi oleh institusi ini baik dari sisi internal maupun eksternal. Penelitian ini mencoba untuk mengidentifikasi penyebab serta faktor-faktor yang dominan menjadi hambatan dalam pengembangan LKMS di Indonesia, dengan pendekatan metode BOCR Analytic Network Process (ANP), termasuk solusi strategis yang diusulkan. Berdasarkan urutan prioritas, maka alternatif aspek menunjukkan bahwa aspek technical menjadi aspek prioritas, selanjutnya diikuti oleh aspek legal/ structure, pasar/ komunal, dan SDM. Penguraian solusi secara keseluruhan menghasilkan urutan prioritas 1) Pembinaan/ sosialisasi/ pendampingan masyarakat menjadi prioritas utama, selanjutnya diikuti oleh 2) inovasi produk, 3) 
lokasi strategis, 4) kerjasama dengan LKS lainnya, dan 5) menjadikan elemen eksternal sebagai pusat informasi dan media sosialisasi. Sedangkan prioritas strategi yang dianggap dapat meningkatkan pengembangan LKMS di Indonesia terdiri dari: 1) mengoptimalkan peran pemerintah dalam pendanaan, 2) melakukan koordinasi dengan PINBUK, dan 3) linkage program LKMS-BMT-BPRSBank Umum Syariah.

\section{METODE PENELITIAN}

Metode penelitian pada dasarnya merupakan cara ilmiah untuk mendapatkan data dengan tujuan dan kegunaan tertentu. Berdasarkan hal tersebut terdapat empat kata kunci yang perlu diperhatian yaitu, cara ilmiah, data, tujuan, dan kegunaan (Sugiyono, 2017). Secara umum metode penelitian didefinisikan sebagai suatu kegiatan ilmiah yang terencana, terstruktur, sistematis, dan memiliki tujuan tertentu baik praktis maupun teoritis (Raco, 2010). Setiap penelitian mempunyai tujuan dan kegunaan tertentu. Secara umum tujuan penelitian ada tiga macam yaitu yang bersifat penemuan, pembuktian dan pengembangan.

Dalam penelitian ini menggunakan metode kualitatif. Dimana metode kualitatif sendiri adalah metode penelitian yang berlandaskan pada filsafat postpositivisme, digunakan untuk meneliti pada kondisi obyek alamiah, (sebagai lawannya adalah eksperimen) dimana peneliti adalah sebagai instrument kunci, teknik pengumpulan data dilakukan secara triangulasi (gabungan), analisis data bersifat induktif/kualitatif, dan hasil penelitian kualitatif lebih menekankan makna dari generalisasi (Sugiyono, 2017)..

Jenis penelitian yang digunakan dalam penelitian ini adalah field research (penelitian lapangan), atau dapat pula dikatakan sebagai penelitian empiris atau sosiologis. Dimana dalam penelitian ini menitik beratkan pada hasil-hasil pengumpulan data yang didapatkan secara langsung di Lapangan, dari para informan atau nara sumber yang telah ditentukan (Sugiyono, 2017). Informan tersebut di antaranya adalah Manager KSPPS BMT Purwakarta Amanah Sejahtera, Staff Pembiayaan \& Lapangan KSPPS BMT Purwakarta Amanah Sejahtera.

Adapun pendekatan yang digunakan dalam penelitian ini adalah pendekatan deskriptifkualitatif. Penelitian deskriptif adalah suatu penelitian yang bertujuan untuk membuat deskripsi atau gambaran atau lukisan secara sistematis mengenai suatu fenomena yang terjadi di masyarakat (Sugiyono, 2015). Dalam penelitian ini, penulis menggambarkan sistem model dan implementasi pembiayaan ultra mikro yang ada di KSPPS BMT Purwakarta Amanah Sejahtera.

Creswell mendefinisikannya sebagai suatu pendekatan atau penelusuran untuk mengeksplorasi dan memahami suatu gejala sentral (Raco, 2010). Penelitian ini mencoba untuk meminta orang-orang untuk mengungkapkan berbagai pikiran mereka tentang suatu topik tanpa memberi mereka banyak arahan atau pedoman bagaimana harus berkata apa.

Menurut moleong penelitian kualitatif adalah penelitian yang bermaksud untuk memahami fenomena tentang apa yang dialami oleh subjek penelitian misalnya perilaku, persepsi, motivasi, tindakan dan lain-lain. Secara holistik dan dengan cara deskripsi dalam bentuk kata-kata dan bahasa, pada suatu konteks khusus yang alamiah dengan memanfaatkan berbagai metode alamiah (Moleong, 2017).

Penelitian kualitatif bertujuan untuk menjelaskan fenomena melalui pengumpulan data data sedalam-dalamnya. Penelitian ini tidak mengutamakan besarnya populasi atau sampling, bahkan samplenya sangat terbatas. 
Jika data yang terkumpul sudah mendalam dan bisa menjelaskan fenomena yang diteliti, maka tidak perlu mencari sampling lainnya. Penelitian kualitatif lebih menekankan pada persoalan kedalaman (kualitas) data bukan banyaknya (kuantitas) data (Kriyantono \& Rachmat, 2009).

Peneliti adalah bagian integral dari data, artinya peneliti ikut aktif dalam menentukan jenis data yang diinginkan. Dengan demikian, peneliti menjadi instrument penelitian yang harus terjun langsung di lapangan. Karena itu, penelitian kualitatif bersifat subjektif dan hasilnya lebih kasuistik, bukan untuk digeneralisasikan. Desain penelitian dapat berubah atau disesuaikan dengan perkembangan penelitian. Secara umum, penelitian yang menggunakan metodologi kualitatif mempunyai ciri-ciri sebagai berikut (Kriyantono \& Rachmat, 2009):

1. Intensif, partisipasi peneliti dalam waktu lama pada setting lapangan, peneliti adalah instrument pokok penelitian.

2. Perekaman yang sangat hati-hati terhadap apa yang terjadi dengan catatan-catatan di lapangan. Dan tipe-tipe lain dari buktibukti dokumenter.

3. Analisis data lapangan, melalui data hasil observasi dengan pedoman yang sudah divalidasi.

4. Melaporkan hasil termasuk deskripsi detail, quotes (kutipan-kutipan) dan komentar-komentar.

5. Tidak ada realitas yang tunggal setiap peneliti mengkreasi realitas sebagai bagian dari proses penelitiannya. Realitas dipandang dinamis dan sebagai produk kontruksi sosial.

6. Subjektif dan berada ha nya dalam referensi peneliti. Peneliti sebagai sarana penggalian interpretasi data.

7. Realitas adalah holistik dan tidak dapat dipilah-pilah.
8. Peneliti memproduksi penjelasan unik tentang situasi yang terjadi dan individuindividunya.

9. Lebih pada kedalaman (depth) daripada keluasan (breadth).

10. Prosedur penelitian: empiris-rasional dan tidak berstruktur.

11. Hubungan antara teori, konsep, dan data: data memunculkan atau membentuk teori baru.

Metode yang digunakan dalam penelitian ini adalah metode penelitian deskriptif kualitatif karena peneliti ingin menggambarkan atau melukiskan fakta-fakta atau keadaan yang tampak pada BMT Purwakarta Amanah Sejahtera (PAS) meliputi model pembiayaan ultra mikro, hukum pembiayaan ultra mikro yang berdasarkan prinsip syari'ah, serta implementasi pembiayaan ultra mikro yang ada di KSPPS BMT PAS.

Dalam sebuah penelitian, sumber data adalah hal yang paling utama dan juga yang paling penting. Sumber data adalah subjek dari mana data tersebut dapat diperoleh. Sejalan dengan penelitian ini sumber data yang digunakan adalah sumber data primer. Sumber data primer didapatkan secara langsung dari hasil observasi dan wawancara secara langsung yang dilakukan dengan pimpinan, pegawai, dan anggota KSPPS BMT PAS. Kriteria pemilihan informan anggota BMT yang akan diwawancara didasarkan pada tiga hal, yaitu sebagai berikut:

1. Diatas usia 19 tahun.

Disini peneliti mengambil 4 orang informan sebagai sumber data, satu orang Manager dari pihak KSPPS BMT PAS, satu orang Staff Lapangan KSPPS BMT PAS, dan dua orang Anggota KSPPS BMT PAS dari jumlah anggota 264 anggota.

\section{Anggota aktif}


Yang dimaksud anggota aktif adalah anggota yang aktif membayar simpanan wajib setiap bulannya.

3. Anggota yang melakukan pembiayaan ultra mikro.

Informan pada penelitian ini adalah anggota yang berusia 19 tahun keatas karena usia itu dinilai sudah cukup mampu memberikan pendapat dan pernyataan yang tidak berubah-ubah.

Dalam penelitian kualitatif, data utama diperoleh dari peneliti sendiri yang secara langsung mengumpulkan informasi yang didapat dari observasi dan subjek penelitian yaitu pimpinan, pegawai dan anggota KSPPS BMT PAS. Penelitian ini dilakukan secara intensif lewat observasi dan wawancara dengan informan serta penelaahan melalui literatur.

Metode pengumpulan data adalah teknik atau cara-cara yang dapat digunakan untuk mengumpulkan data. Ada beberapa teknik atau metode pengumpulan data yang biasanya dilakukan oleh peneliti. Peneliti dapat menggunakan salah satu atau gabungan dari metode yang ada tergantung masalah yang dihadapi (Kriyantono \& Rachmat, 2009). Teknik pengumpulan data yang digunakan dalam penelitian ini, antara lain:

\section{Observasi}

Observasi adalah bagian dari pengumpulan data. Observasi berarti mengumpulkan langsung dari lapangan. Dalam tradisi kualitatif, data tidak akan diperoleh dibelakang meja, tetapi harus terjun langsung ke lapangan, ke tetangga, ke organisasi, ke komunitas. Data yang diobservasi dapat berupa gambaran tentang sikap, kelakuan, perilaku, tindakan, interaksi antar manusia (Raco, 2010).

Nasution menyatakan bahwa, observasi adalah dasar semua ilmu pengetahuan, para ilmuwan hanya dapat bekerja berdasarkan data, yaitu fakta mengenai dunia kenyataan yang diperoleh melalui observasi. Data itu dikumpulkan dan sering dengan bantuan berbagai alat yang sangat canggih.

Marshall menyatakan bahwa melalui observasi, peneliti belajar tentang perilaku, dan makna dari perilaku tersebut.

Sanafiah Faisal mengklarifikasikan observasi menjadi observasi berpartisipasi, observasi yang seara terang-terangan dan tersamar, dan observasi yang tidak berstruktur (Sugiyono, 2017). Dalam hal ini peneliti akan menggunakan metode Observasi partisipasi di KSPPS BMT Purwakarta Amanah Sejahtera (PAS). Dalam observasi ini, peneliti terlibat dengan kegiatan sehari-hari orang yang sedang diamati atau yang digunakan sebagai sumber data penelitian. Sambil melakukan pengamatan,peneliti ikut melakukan apa yang dikerjakan oleh sumber data, dan ikut merasakan suka dukanya. Dengan observasi partisipan ini, maka data yang diperoleh akan lebih lengkap, tajam, dan sampai mengetahui pada tingkat makna dari setiap perilaku yang Nampak (Sugiyono, 2017).

2. Wawancara

Teknik yang digunakan dalam pengumpulan data dalam penelitian ini menggunakan wawancara. Wawancara adalah percakapan dengan maksud tertentu. Percakapan itu dilakukan oleh dua pihak, yaitu pewawancara yang mengajukan pertanyaan dan informan yang memberikan jawaban atas pertanyaan yang diajukan pewawancara. Maksud mengadakan wawancara, seperti ditegaskan Lincoln dan Guba dalam moleong antara lain: mengkontruksi mengenai orang, kejadian, organisasi, perasaan, motivasi, tuntunan, kepedulian, dan lain-lain (Moleong, 2017).

Esterberg mendefinisikan wawancara atau interview merupakan pertemuan dua orang 
untuk bertukar informasi dan ide melalui tanya jawab, sehingga dapat dikonstruksikan makna dalam suatu topik tertentu (Sugiyono, 2017).

Jenis wawancara yang digunakan dalam penelitian ini adalah wawancara baku terbuka, yakni menggunakan pertanyaan baku. Urutan pertanyaan, kata-kata, dan cara penyajiannya pun sama untuk setiap informan. Keluwesan mengadakan pertanyaan pendalaman (probing) terbatas, dalam hal itu, bergantung situasi wawancara dan kecakapan pewawancara. Wawancara demikian digunakan jika dipandang sangat perlu untuk mengurangi sedapat-dapatnya variasi yang bisa terjadi antara seorang terwawancara dengan yang lainnya. Maksud pelaksanaan tidak lain merupakan usaha untuk menghilangkan kemungkinan terjadi kekeliruan (Moleong, 2017).

Secara spesifik agar lebih mudah wawancara digunakan dengan teknik wawancara terstruktur karna peneliti menetapkan masalah dan pertanyaanpertanyaan yang akan diajukan dengan menyiapkan instrumen penelitian berupa pertanyaan-pertanyaan tertulis. Selain itu, peneliti juga membawa alat wawancara diantaranya: buku catatan dan tape recorder.

3. Dokumentasi

Dokumen merupakan catatan peristiwa yang sudah berlalu. Dokumen bisa berbentuk tulisan, gambar, atau karyakarya monumental dari seseorang. Dokumen yang berbentuk tulisan misalnya catatan harian, sejarah kehidupan, biografi, peraturan, kebijakan, dan dokumen yang berbentuk gambar misalnya foto, gambar hidup, sketsa, dan lain-lain. Sedangkan dokumen yang berbentuk karya misalnya karya seni, yang dapat berupa gambar, patung, film, dan lain-lain. Studi dokumen merupakan pelengkap dari penggunaan metode observasi dan wawancara dalam penelitian kualitatif.

Secara detail, bahan dokumenter terbagi beberapa macam, yaitu autobiografi, surat pribadi, buku atau catatan harian, memorial, klipping, dokumen pemerintah atau swasta, data di server dan flashdisk, dan data tersimpan di web site.

Dalam melakukan analisis data berarti mengatur secara sistematis bahan hasil wawancara dan observasi, menafsirkannya dan menghasilkan suatu pemikiran, pendapat, teori atau gagasan yang baru. Semuanya diringkas dengan istilah penegasan yang memiliki arti (Raco, 2010).

Definisi analisis data menurut Bogdan adalah proses mencari dan menyusun secara sistematis data yang diperoleh dari hasil wawancara, catatan lapangan, dan bahanbahan lain, sehingga dapat mudah dipahami, dan temuannya dapat diinformasikan kepada orang lain. Analisis data dilakukan dengan mengorganisasikan data, menjabarkanya ke unit-unit, melakukan sintesa, menyusun kedalam pola, memilih mana yang penting dan yang akan dipelajari, dan membuat kesimpulan yang dapat diceritakan kepada orang lain (Sugiyono, 2015).

Sementara Susan Stainback
mengemukakan bahwa "analisis data merupakan hal yang kritis dalam proses penelitian kualitatif. Analisis digunakan untuk memahami hubungan dan konsep dalam data sehingga hipotesis dapat dikembangkan dan di evaluasi". Spraley menyatakan bahwa: "Analisis dalam pengertian apapun, adalah merupakan cara berfikir. Hal itu berkaitan dengan pengujian secara sistematis terhadap sesuatu untuk menentukan bagian, hubungan antar bagian, dan hubungannya dengan keseluruhan. Analisis adalah untuk mencari pola. 
Berdasarkan hal tersebut di atas dapat disimpulkan bahwa, analisis data adalah proses mencari dan menyusun secara sistematis data yang diperoleh dari hasil wawancara, catatan lapangan, dan dokumentasi, dengan cara mengorganisasikan data kedalam kategori, menjabarkan ke unitunit, melakukan sintesa, menyusun kedalam pola, memilih mana yang penting dan yang akan dipelajari, dan membuat kesimpulan sehingga mudah difahami oleh diri sendiri maupun orang lain.

Teknik penelitian yang digunakan dalam penelitian ini yaitu analisis Miles dan Huberman. Dimana Miles dan Huberman, mengemukakan bahwa aktivitas dalam analisis data kualitatif dilakukan seara interaktif dan berlangsung secara terus menerus sampai tuntas, sehingga datanya sudah jenuh. Aktivitas dalam analisis data, yaitu (Sugiyono, 2016):

1. Data Reduction (Reduksi Data)

Mereduksi data berarti merangkum, memilih hal-hal yang pokok, memfokuskan pada hal-hal yang pokok, memfokuskan pada hal-hal yang penting, dicari tema dan polanya dan membuang yang tidak perlu (Sugiyono, 2017). Dari sekian banyak jumlah data yang diperoleh dari lapangan, maka peneliti harus melakukan reduksi data secara teliti dan rinci. Dengan demikian data yang direduksi akan memberikan gambaran yang lebih jelas, dan mempermudah peneliti untuk melakukan pengumpulan data selanjutnya.

Dalam penelitian ini hasil data yang didapatkan dilapangan baik berupa catatan, rekaman suara, dokumentasi, serta berdasarkan data primer lainnya akan disatukan. Kemudian direduksi untuk mencari tema atau pola agar lebih sesuai dengan tujuan awal penelitian.

2. Data Display (penyajian data)
Dalam penelitian kualitatif, penyajian data bisa dilakukan dalam bentuk uraian singkat, bagan, hubungan antar kategori, flowchart dan sejenisnya. Dalam hal ini Miles and Huberman menyatakan "yang paling sering digunakan untuk menyajikan data dalam penelitian kualitatif adalah dengan teks yang bersifat naratif' (Sugiyono, 2017).

Kemudian, setelah data direduksi dilanjutkan dengan mendisplaykan data atau penyajian data seperti yang dijelaskan diatas peneliti membuat uraian singkat atau naratif yang diungkapkan dari hasil data yang didapatkan di lapangan sesuai dengan yang dipahami oleh peneliti, dan tidak keluar dari teori-teori yang berkaitan dengan topik-topik penelitian.

3. Counslusion

Drawing/Verificatio

(Kesimpulan).

Langkah ke tiga dalam analisis data kualitatif menurut Miles and Huberman adalah penarikan kesimpulan dan verifikasi. Kesimpulan awal yang dikemukakan masih bersifat sementara, dan akan berubah bila tidak ditemukan bukti-bukti yang kuat yang mendukung pada tahap pengumpulan data berikutnya. Tetapi apabila kesimpulan yang dikemukakan pada tahap awal, didukung oleh bukti-bukti yang valid dan konsisten saat peneliti kembali ke lapangan mengumpulkan data, maka kesimpulan yang dikemukakan merupakan kesimpulan yang kredibel.

Dengan demikian kesimpulan dalam penelitian kualitatif mungkin dapat menjawab rumusan masalah yang dirumuskan sejak awal, tetapi mungkin juga tidak, karena seperti telah dikemukakan bahwa masalah dan rumusan masalah dalam penelitian kualitatif masih bersifat sementara dan 
akan berkembang setelah penelitian berada di lapangan.

\section{HASIL DAN PEMBAHASAN A.Model Pembiayaan Ultra Mikro di KSPPS BMT Purwakarta Amanah Sejahtera (PAS)}

Pelaksanaan pembiayaan ultra mikro di KSPPS BMT PAS berdasarkan wawancara yang telah dilakukan dengan pihak KSPPS BMT PAS, Menurut Bapak Agah Nugraha selaku Manager KSPPS BMT PAS, mengatakan bahwa pembiayaan ultra mikro di KSPPS BMT PAS tidak ada model sistem kelompok atau tanggung renteng. Karena, menurut Beliau sistem tanggung renteng tidak sesuai dengan sunnah dan Hukum Ekonomi Syariah. Sehingga di KSPPS BMT PAS tidak menggunakan sistem tanggung renteng (Nugraha, 2019).

Pengguna pembiayaan ultra mikro di KSPPS BMT PAS kebanyakan adalah para pedagang kecil atau para pelaku UMKM yang membutuhkan biaya tambahan untuk modal usahanya. Konsep angsuran yang digunakan dalam pembiayaan ultra mikro di KSPPS BMT PAS adalah mingguan dan bulanan, untuk mingguan maksimal 25 minggu, dan untuk bulanan maksimal 12 bulan.

Menurut data dari website resmi kementrian keuangan, batas maksimal pembiayaan ultra mikro secara umum adalah Rp 10 juta. Sedangkan untuk di KSPPS BMT PAS sendri batas maksimal pengajuannya adalah Rp 5 juta, dan minimal pengajuannya Rp 300 ribu. Karena pada dasarnya pembiayaan ultra mikro hanya untuk melayani pembiayaan-pembiayaan kecil yang dibutuhkan oleh para pelaku usaha kecil. Sehingga batas pembiayaannya tidak begitu besar. Untuk pengajuan jumlah pembiayaannya dengan cara bertahap yaitu dari kecil sampai maksimal Rp 5 juta. Apabila selama proses angsuran tidak ada masalah dan lancar sampai waktu yang telah ditentukan, maka anggota bisa melakukan pembiayaan kembali dengan jumlah yang lebih besar dari sebelumnya

Dalam pembiayaan ultra mikro terdapat dua jenis pembiayaaan ultra mikro menurut fatwa DSN-MUI. Termasuk dalam pelaksanaannya di KSPPS BMT PAS terdapat dua jenis pembiayaan ultra mikro diantaranya:

1. Pembiayaan Ultra Mikro Multijasa

Pembiayaan ultra mikro multijasa adalah pembiayaan ultra mikro yang obyeknya berupa jasa yang beragam, atau barang dan jasa yang jasanya lebih dominan.

2. Pembiayan Ultra Mikro Multibarang

Pembiayaan ultra mikro multibarang adalah pembiayaan ultra mikro yang obyeknya berupa barang yang beragam, atau barang dan jasa yang barangnya lebih dominan (Fatwa DSN-MUI Nomor 119/DSN-MUI/II/2018 Tentang Pembiayaan Ultra MIkro Berdasarkan Prinsip Syariah, 2018).

Dalam pelaksanaannya di KSPPS BMT PAS berdasarkan data yang didapatkan, pembiayaan ultra mikro multijasa dan pembiayaan ultra mikro multibarang hampir sama jumlah penggunanya. Untuk pembiayaan ultra mikro multibarang kebanyakan menggunakan akad Murabahah, dan untuk pembiayaan ultra mikro multijasa menggunakan akad Ijarah secara Wakalah.

Pembiayaan ultra mikro multibarang yang dilakukan di KSPPS BMT PAS berbentuk barang yang konsumtif seperti alat elektronik, alat komunikasi dan lain sebagainya. Sedangkan untuk pembiayaan ultra mikro multibarang di KSPPS BMT PAS contohnya untuk pembiayaan anak sekolah dan lain sebagainya..

Dari hasil observasi dan wawancara yang dilakukan dengan Manager KSPPS BMT 
PAS syarat untuk pengajuan pembiayaan ultra mikro sebagai berkut:

\section{Menjadi Anggota KSPPS BMT PAS} Untuk menjadi anggota di KSPPS BMT PAS caranya dengan mengumpulkan fotocopy KTP dan membayar Rp. 100.000 dengan rincian sebagai berikut:
a. Rp. 50.000 untuk simpanan pokok
b. 10.000 untuk simpanan wajib
c. Rp. 20.000 untuk tabungan atau saldo awal tabungan

d. Rp. 20.000 untuk administrasi

Syarat yang paling penting dalam pembiayaan ultra mikro harus menjadi anggota. Karena di KSPPS BMT PAS menggunakan aplikasi Micro Banking System yaitu aplikasi yang digunakan KSPPS BMT PAS untuk pencatatan keuangan. Jadi, apabila ada orang non anggota yang melakukan pembiayaan akan sulit untuk memasukan datanya. Sehingga jika ada yang ingin melakukan pembiayaan di KSPPS BMT PAS harus daftar menjadi anggota terlebih dahulu.

2. Menjadi Anggota Aktif

Kategori anggota aktif yang dimaksud adalah anggota yang aktif dalam membayar simpanan wajib setiap bulannya

pelaksanaan pembiayaan ultra mikro di BMT terdapat beberapa prosedur yang dilakukan BMT dalam melakukannya. Dari hasil wawancara dan observasi diperoleh prosedur sebagai berikut:

1. Anggota mengajukan pembiayaan terlebih dahulu kepada KSPPS BMT PAS mengenai kebutuhan yang diperlukan. Dengan memberikan fotocopy Kartu Tanda Penduduk (KTP).

2. Pihak KSPPS BMT PAS melakukan analisis kebutuhan terhadap anggota tersebut. Yang kemudian akan disesuaikan dengan Standart Operasional Prosedur yang ada di KSPPS BMT PAS.
3. KSPPS BMT PAS akan melakukan survey kepada anggota yang melakukan pengajuan. Survey inilah yang akan menentukan kualitas ataupun nanti di setujui atau tidaknya pembiayaan yang diajukan anggota.

4. Apabila di setujui pembiayaannya, maka bisa dari pihak KSPPS BMT PAS atau anggota yang datang ke kantor untuk proses dilakukannya akad dan pencairan.

Dalam pelaksanaan prosedur pembiayaan ultra mikro di BMT KSPPS BMT PAS dibuat lebih mudah dan tidak dipersulit. Karena menurut Bapak Agah Nugraha selaku Manager KSPPS BMT PAS mengatakan "Yassiru wala tuasiru" mudahkan jangan mempersulit. Sehingga semuanya dikemas secara praktis tidak mempersulit atau memberatkan kepada anggota.

Jumlah total anggota di KSPPS BMT PAS bahwasannya keseluruhan anggota di KSPPS BMT PAS berjumlah 264 anggota. Dari total keseluruhan jumlah anggota, ada beberapa anggota yang melakukan akad pembiayaan, diantaranya:

\begin{tabular}{|c|c|}
\hline Akad Murabahah & 252 \\
\hline Akad Musyarakah & 4 \\
\hline Akad Rahn & 10 \\
\hline $\begin{array}{c}\text { Akad Wakalah bil } \\
\text { Ujrah }\end{array}$ & 95 \\
\hline Akad Qard & 15 \\
\hline
\end{tabular}

Dari hasil wawancara yang dilakukan dengan 2 orang anggota KSPPS BMT PAS keduanya mengatakan bahwa dengan adanya pembiayaan ultra mikro di KSPPS BMT PAS sangat terbantu dalam menambah modal usaha. Kebanyakan anggota yang mengajukan pembiayaan di KSPPS BMT PAS adalah para pedagang dan para pelaku usaha kecil lainya. Rata-rata yang mengajukan pembiayaan untuk keperluan 
modal usahanya atau untuk menambah modal usahanya.

Dalam pelaksanaannya untuk proses pengajuan pembiayaan, KSPPS BMT PAS tidak mempersulit anggotanya. Hanya saja untuk nominal yang diajukan, pihak KSPPS BMT PAS tidak bisa langsung memberikan pembiayaan berjumlah besar, tetapi secara bertahap dari pengajuan pertama berjumlah Rp 2 juta dan jika anggota tidak bermasalah selama pembayaran maka apabila mengajukan lagi, akan bertambah jumlahnya tidak Rp 2 juta lagi.

Sanksi yang dilakukan KSPPS BMT PAS untuk anggota yang bermasalah dalam angsurannya, yaitu dengan cara melakukan sanksi sosial dan moral kepada anggota yang bermasalah tersebut. Dimana, pihak KSPPS BMT PAS mendatangi dan menagih secara terus-menerus ke rumah anggota setiap harinya, sehingga akan membuat anggota malu secara tidak langsung akibat sering di datangi oleh pihak KSPPS BMT PAS. Meskipun anggota yang bermasalah tidak ada di rumahnya, akan tetap terus didatangi oleh pihak KSPPS BMT PAS. Sehingga dengan cara seperti itu, anggota akan memaksakan untuk membayarnya. Apabila anggota tersebut belum mempunyai uang sesuai dengan jumlah angsurannya, maka pihak KSPPS BMT PAS akan menanyakan langsung apa masalah nya, dan jika memang masih kurang uang setorannya, maka pihak KSPPS BMT PAS akan menerima berapapun jumlah uang sesuai dengan kesanggupan anggota tersebut (Nanang (Staff Pembiayaan dan Lapangan KSPPS BMT Purwakarta Amanah), 2019).

Bagan 4.1

Flowchart Prosedur Pembiayaan Ultra Mikro di KSPPS BMT PAS

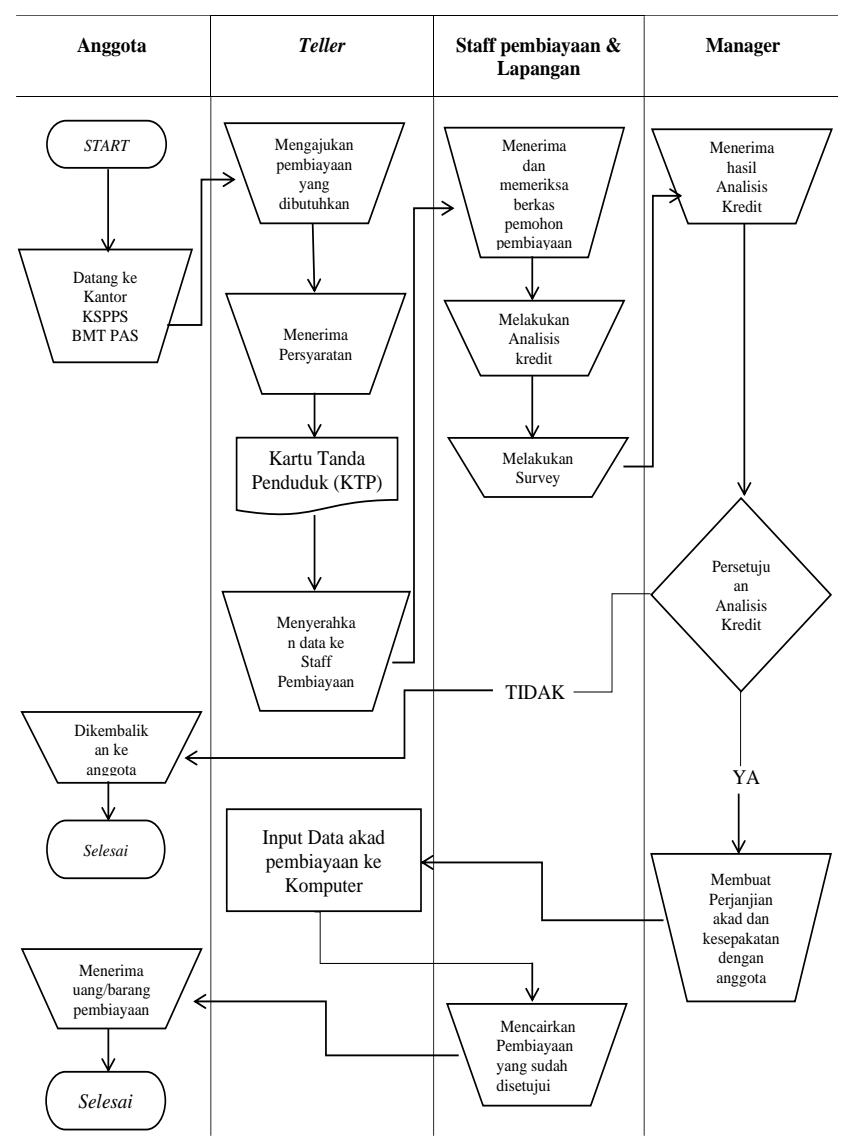

Sumber: Diolah oleh Peneliti

\section{B. Implementasi Pembiayaan Ultra Mikro di KSPPS BMT Purwakarta Amanah Sejahtera (PAS) Berdasarkan Prinsip Syariah.}

Pada dasarnya pembiayaan Ultra Mikro adalah pembiayaan yang dilakukan untuk menjangkau para pelaku UMKM paling kecil atau ultra mikro yang tidak terjangkau oleh perbankan, yang dikarenakan regulasi persyaratannya tidak bisa dipenuhi oleh para pelaku usaha mikro atau paling kecil. Selain itu, dalam perbankan sendiri tidak bisa menerima pembiayaan kecil yang dibawah Rp 10 juta.

Dengan adanya pembiayaan ultra mikro ini sangat membantu masyarakat khususnya para pelaku usaha yang berada dilapisan bawah, karena pada pembiayaan ultra mikro ini salah satu yang memudahkannya adalah dengan tidak adanya anggunan, serta 
pembiayaan yang kecilpun bisa diterima oleh lembaga keuangan.

Pembiayaan ultra mikro ini dilakukan oleh lembaga keuangan Non Bank, salah satunya adalah lembaga koperasi, baik koperasi konvensional ataupun koperasi syariah. Pada lembaga koperasi, khususnya koperasi syariah pembiayaan ultra mikro dilakukan oleh KSPPS BMT PAS. Dalam penelitian ini, peneliti melakukan penelitian di KSPPS BMT Purwakarta Amanah Sejahtera (PAS).

Pembiayaan ultra mikro diatur dalam fatwa Nomor 119/DSN-MUI/II/2018 tentang pembiayaan ultra mikro berdasarkan prinsip syariah. Sehingga dalam pelaksanaannya harus sesuai dengan ketentuan yang ada dalam fatwa DSN-MUI. Dalam pembiayaan UMi menurut fatwa DSN-MUI terdapat beberapa jenis dan bentuk akad diantaranya:

1. Pembiayaan Ultra Mikro Multibarang
a. Akad Jual Beli
b. Akad Jual Beli Murabahah
c. Akad Jual Beli Salam
d. Akad Jual Beli Istishna'

2. Pembiayaan Ultra Mikro Multijasa
a. Akad Ijarah
b. Akad Kafalah

Pelaksanaan pembiayaan UMi di KSPPS BMT PAS dari hasil observasi dan wawancara di lapangan diperoleh bahwa akad yang sering digunakan dalam pembiayaan UMi di KSPPS BMT PAS adalah akad Murabahah.

Menurut fatwa DSN-MUI nomor 119/DSN-MUI/II/2018 dalam pelaksanaan pembiayaan UMi, jika menggunakan akad jual-beli murabahah, maka wajib tunduk dan patuh pada ketentuan (dhawabith) dan batasan (hudud) yang terdapat dalam fatwa DSN-MUI nomor 04/DSN-MUI/IV/2000 tentang Murabahah

\section{Penerapan Akad Murabahah Ultra Mikro di KSPPS BMT PAS}

Menurut fatwa DSN-MUI nomor 111/DSN-MUI/IX/2017 tentang akad jual beli murabahah, menyatakan bahwa akad murabahah adalah akad jual beli suatu barang dengan menegaskan harga belinya kepada pembeli dan pembeli membayarnya dengan harga yang lebih sebagai laba (Fatwa DSNMUI Nomor 111/DSN-MUI/IX/2017 Tentang Akad Jual Beli Murabahah, 2017). Kemudian untuk ketentuan akad murabahah diatur dalam fatwa DSN-MUI nomor 04/DSN-MUI/IV/2000 tentang murabahah.

Pelaksanaan akad murabahah di KSPPS BMT PAS merupakan pembiayaan yang paling banyak dilakukan diantara akad lain yang ada di KSPPS BMT PAS. Hal ini menjadi dasar peneliti untuk melakukan penelitian lebih dalam mengenai akad murabahah yang ada di KSPPS BMT PAS. Selain itu, akad murabahah termasuk salah satu akad yang ada di pembiayaan ultra mikro. Sehingga peneliti mengambil sample akad pembiayaan ultra mikro yang paling banyak digunakan di KSPPS BMT PAS.

Dari hasil observasi dan wawancara yang telah dilakukan di KSPPS BMT PAS, pelaksanaan akad murabahah di KSPPS BMT PAS berupa barang-barang yang konsumtif seperti alat-alat elektronik, alatalat komunikasi, dan lain sebagainya. Mekanisme pelaksanaannya yaitu pertama anggota mengajukan keperluan akan barang yang dibutuhkan ke KSPPS BMT PAS, kemudian KSPPS BMT PAS melakukan survey harga barang yang dibutuhkan. Setelah itu, KSPPS BMT PAS melakukan kesepakatan dengan anggota terkait harga pokok dan margin yang ditetapkan, dan apabila sudah terjadi kesepakatan antara pihak KSPPS BMT PAS dengan anggota, maka KSPPS BMT PAS melakukan pembelian akan barang tersebut. Untuk 
pembayarannya bisa dengan cara diangsur (taqsith) atau dengan cara tempo (muazza). Setelah itu, dilakukan akad sesuai dengan administrasi yang ada di KSPPS BMT PAS. Untuk biaya administrasinya sebagai berikut:

a. Rp. 20.000 untuk administrasi setiap melakukan akad, berapapun jumlah pembiayaannya.

b. $1 \%$ dari jumlah pembiayaan untuk dana tabarru.

c. $1 \%$ dari jumlah pembiayaan untuk infaq baitul mal

Selain barang-barang yang konsumtif, KSPPS BMT PAS juga menerima pembiayaan akad murabahah untuk keperluan modal usaha. Tetapi, dalam pelaksanaan akad murabahah untuk keperluan modal usaha, BMT mengunakan akad tambahan yaitu akad wakalah. Jadi, anggota mengajukan pembiayaan ke KSPPS BMT PAS. Namun, yang membelikan barangnya bukan dari pihak KSPPS BMT PAS, melainkan orang yang akan berdagang atau anggota yang mengajukan. Karena pihak KSPPS BMT PAS mengalami kesulitan dalam melakukan pembelian yang dibutuhkan anggota. Sehingga, KSPPS BMT PAS mewakilkan kepada anggota untuk membelikan keperluan untuk bahan usahanya - Sebab, yang lebih paham mengenai kebutuhan untuk usahanya adalah pelaku usaha itu sendiri. Nanti setelah dilakukan pembelian barang yang dibutuhkan anggota memberikan bukti berupa kuitansi dari hasil belanjanya itu diserahkan kepada pihak KSPPS BMT PAS sebagai bukti dari pembiayaannya, paling lama 5 hari kerja.

Sehingga dapat diperoleh penyesuaian penerapan antara fatwa DSN-MUI Nomor 04/DSN-MUI/IV/2000 dan praktek di Lapangan pada tabel sebagai berikut:
Tabel 4.1

Penerapan Akad Murabahah

\begin{tabular}{|c|c|c|c|}
\hline \multirow[t]{2}{*}{ No } & \multirow{2}{*}{$\begin{array}{c}\text { Fatwa DSN-MUI } \\
\text { Nomor 04/DSN-MUI/IV/2000 }\end{array}$} & \multicolumn{2}{|c|}{$\begin{array}{c}\text { Kesesuaian } \\
\text { Syariah }\end{array}$} \\
\hline & & Sesuai & Tidak \\
\hline 1 & $\begin{array}{l}\text { Lembaga keuangan dan anggota } \\
\text { harus melakukan akad murabahah } \\
\text { yang bebas riba. }\end{array}$ & $\checkmark$ & \\
\hline 2 & $\begin{array}{l}\text { Barang yang diperjual belikan } \\
\text { tidak diharamkan oleh syariah } \\
\text { Islam. }\end{array}$ & $\checkmark$ & \\
\hline 3 & $\begin{array}{l}\text { Lembaga keuangan membiayai } \\
\text { sebagian atau seluruh harga } \\
\text { pembelian barang yang telah } \\
\text { disepakati kualifikasinya. }\end{array}$ & $\checkmark$ & \\
\hline 4 & $\begin{array}{l}\text { Lembaga keuangan membeli } \\
\text { barang yang diperlukan anggota } \\
\text { atas nama bank sendiri, dan } \\
\text { pembelian ini harus sah dan bebas } \\
\text { riba. }\end{array}$ & $\checkmark$ & \\
\hline 5 & $\begin{array}{l}\text { Lembaga keuangan harus } \\
\text { menyampaikan semua hal yang } \\
\text { berkaitan dengan pembelian, } \\
\text { misalnya jika pembelian } \\
\text { dilakukan secara utang. }\end{array}$ & $\checkmark$ & \\
\hline 6 & $\begin{array}{l}\text { Lembaga keuangan kemudian } \\
\text { menjual barang tersebut kepada } \\
\text { anggota (pemesan) dengan harga } \\
\text { jual senilai harga beli plus } \\
\text { keuntungannya. } \\
\text { Dalam kaitan ini Bank harus } \\
\text { memberitahu secara jujur harga } \\
\text { pokok barang kepada anggota } \\
\text { berikut biaya yang diperlukan. }\end{array}$ & $\checkmark$ & \\
\hline 7 & $\begin{array}{l}\text { Anggota membayar harga barang } \\
\text { yang telah disepakati tersebut } \\
\text { pada jangka waktu tertentu yang } \\
\text { telah disepakati. }\end{array}$ & $\checkmark$ & \\
\hline 8 & $\begin{array}{l}\text { Untuk mencegah terjadinya } \\
\text { penyalahgunaan atau kerusakan } \\
\text { akad tersebut, pihak bank dapat } \\
\text { mengadakan perjanjian khusus } \\
\text { dengan anggota. }\end{array}$ & $\checkmark$ & \\
\hline 9 & $\begin{array}{l}\text { Jika Lembaga keuangan hendak } \\
\text { mewakilkan kepada anggota untuk } \\
\text { membeli barang dari pihak ketiga, } \\
\text { akad jual beli murabahah harus } \\
\text { dilakukan setelah barang secara } \\
\text { prinsip, menjadi milik bank. }\end{array}$ & & $\checkmark$ \\
\hline
\end{tabular}

Sumber: Diolah oleh Peneliti

Berdasarkan Point pertama, lembaga keuangan dan anggota harus melakukan akad murabahah yang bebas riba. Dalam akad murabahah pada dasarnya merupakan praktek jual beli dan dipastikan tidak ada unsur riba. Ketika peneliti melakukan

EKSISBANK (Ekonomi Syariah dan Bisnis Perbankan), Volume 4, Nomor 2, Desember 2020 
observasi dan wawancara di KSPPS BMT PAS selama 3 hari, dimana hari pertama melakukan wawancara bersama Bapak Agah, dari hasil wawancara tersebut, pelaksanaan akad murabahah di KSPPS BMT PAS sama berbentuk praktek jual beli antara anggota dengan pihak KSPPS BMT PAS. Dengan melakukan akad dan kesepakatan di awal sebelum melakukan transaksi ketika barang sudah ada. Kemudian dihari ke 2 peneliti melihat secara langsung proses berlangsungnya akad murabahah yang diakukan secara terbuka, dimana pihak KSPPS BMT PAS menjelaskan mengenai harga barang dan margin kepada anggota. Sehingga semua terjadi secara antarodhin atau saling rela tidak ada pihak yang dirugikan. Jadi, semuanya dilakukan secara terbuka dengan anggota sehingga tidak ada unsur riba dalam setiap melakukan pembiayaan pada akad Murabahah. Sehingga peneliti merasa sudah sesuai dengan syariah.

Kemudian pada point kedua, barang yang diperjual belikan tidak diharamkan oleh syariah Islam. Dalam pelaksanaan di KSPPS BMT PAS, setiap barang yang di perjual belikan dalam akad murabahah di KSPPS BMT PAS menurut hasil wawancara dengan Manager KSPPS BMT PAS, Kebanyakan barang yang diperjual belikan adalah alat-alat elektronik dan alat komunikasi serta kebutuhan untuk modal usaha. Sehingga menurut peneliti, dapat dipastikan barang yang diperjual belikan tidak haram dan sesuai dengan syariah.

Selanjutnya point ketiga, lembaga keuangan membiayai sebagian atau seluruh harga pembelian barang yang telah disepakati kualifikasinya. Dalam pelaksanaannya, KSPPS BMT PAS menyediakan barang terlebih dahulu sebelum dilakukannya akad atau dijual kepada anggota. Jadi, pihak KSPPS BMT PAS membeli dan membiayai terlebih dahulu barang yang diperlukan anggota, sebelum dijual kembali kepada anggota. Dalam hal ini jika dilihat dari point ke tiga sudah sama dan sesuai dengan pelaksanaan di KSPPS BMT PAS. Sehingga peneliti menganggap sudah sesuai syariah.

Kemudian Point keempat, lembaga keuangan membeli barang yang diperlukan anggota atas nama bank sendiri, dan pembelian ini harus sah dan bebas riba. Pelaksanaan akad murabahah di KSPPS BMT PAS selalu menyediakan barang terlebih dahulu sebelum dilakukannya akad. Sehingga pihak KSPPS BMT PAS membeli barang yang diperlukan anggota terlebih dahulu kepada pihak ke tiga. Sehingga, dalam proses akad jual beli yang dilakukan oleh pihak KSPPS dan pemilik toko atau pihak ke tiga tidak ada sangkut pautnya dengan anggota yang mengajukan. Oleh karena itu, barang yang dibeli atas nama KSPPS BMT PAS karena proses akad jual beli yang dilakukan adalah antara pihak KSPPS BMT PAS dan pemilik toko atau pihak ke tiga, dan untuk akad jual belinya pun dilakukan dengan sah dan tanpa ada unsur riba. Sehingga peneliti menganggap sudah sesuai dengan point ke empat dan sesuai berdasarkan syariah.

Lalu point kelima, lembaga keuangan harus menyampaikan semua hal yang berkaitan dengan pembelian, misalnya jika pembelian dilakukan secara utang. Setelah pihak KSPPS BMT PAS sudah membeli barang yang diperlukan oleh anggota, pihak KSPPS BMT PAS menyampaikan hal-hal yang terkait dengan barang yang dibutuhkan anggota tersebut, misalnya apabila barang yang dibutuhkan anggota tidak ada atau ada kendala dalam proses melakukan pembelian barang tersebut. Dalam hal ini peneliti menganggap sudah sesuai dengan point ke lima dan sesuai dengan syariah.

Selanjutnya point keenam, lembaga keuangan kemudian menjual barang tersebut 
kepada anggota (pemesan) dengan harga jual senilai harga beli plus keuntungannya. Dalam kaitan ini Bank harus memberitahu secara jujur harga pokok barang kepada anggota berikut biaya yang diperlukan. Dalam pelaksanaannya di KSPPS BMT PAS apabila barang yang diperlukan anggota sudah ada, pihak KSPPS BMT PAS selalu melakukan kesepakatan dengan anggota sebelum terjadinya akad. Dalam hal ini, KSPPS BMT PAS menyampaikan jumlah harga barang atau harga pokok, kemudian margin yang ditetapkan, administrasi, serta kesanggupan jangka waktu anggota untuk angsurannya. Setelah mencapai kesepakatan dan antarodhin atau saling rela antara anggota dan pihak KSPPS BMT PAS tanpa ada yang diberatkan atau dirugikan, maka pihak KSPPS BMT PAS melakukan akad dan perjanjian akad dengan anggota. Dari proses yang dilakukan, menurut peneliti sudah sesuai dengan point ke enam dan sesuai dengan syariah.

Kemudian point ketujuh, anggota membayar harga barang yang telah disepakati tersebut pada jangka waktu tertentu yang telah disepakati. Setelah pihak KSPPS BMT PAS menyampaikan harga pokok dan margin, pihak KSPPS BMT PAS menyampaikan kesanggupan nominal dan jangka waktu kepada anggota untuk membayar angsurannya. Sistem angsuran di KSPPS BMT PAS ada 2 sitem angsuran, yaitu angsuran mingguan dan bulanan. Namun, dalam hal ini pihak KSPPS BMT PAS sebelumnya melakukan pembinaan terkait kebutuhan anggota dengan disesuaikan berdasarkan pendapatannya dan kemampuan dalam mengansurnya. Apabila kemampuan untuk mengansurnya kecil dan tidak sesuai dengan barang yang dibutuhkannya, maka pihak KSPPS BMT PAS mengusulkan untuk merubah tipe barangnya yang harganya lebih murah agar anggota sanggup untuk membayar angsurannya. Dalam hal ini, menurut peneliti sudah sesuai dengan point ke tujuh.

Selanjutnya point kedelapan, untuk mencegah terjadinya penyalahgunaan atau kerusakan akad tersebut, pihak lembaga keuangan, dapat mengadakan perjanjian khusus dengan anggota. Dari hasil wawancara dan observasi yang dilakukan di KSPPS BMT PAS dalam setiap pelaksanaan pembiayaan dan akad, pihak KSPPS BMT PAS selalu memberikan perjanjian akad antara pihak KSPPS BMT PAS dan anggota, meskipun tidak ada perjanjian khusus, tetapi sipatnya sudah mengikat. Karena, dalam pembiayaan ultra mikro pada akad murabahah jumlahnya kecil tidak lebih dari Rp 5 juta. Sehingga dengan perjanjian akadpun sudah cukup. Sehingga menurut peneliti sesuai dengan syariah, karena dalam setiap pelaksanaannya sudah ada perjanjian akad yang sipatnya mengikat antara pihak KSPPS BMT PAS dengan anggota.

Dan Point yang terakhir, jika lembaga keuangan hendak mewakilkan kepada anggota untuk membeli barang dari pihak ketiga, akad jual beli murabahah harus dilakukan setelah barang secara prinsip, menjadi milik bank. Apabila KSPPS BMT PAS tidak mampu untuk membelikan kebutuhan untuk usaha anggota, maka pihak KSPPS BMT PAS selalu menggunakan akad pelengkap yaitu akad wakalah dengan memberikan kepada anggota untuk membeli kebutuhannya tersebut. Hal ini, tidak sesuai dengan point kesembilan, karna disini pihak KSPPS BMT PAS melakukan akad terlebih dahulu sebelum ada barang. Menurut Manager KSPPS BMT PAS dalam hal ini menggunakan prinsip Hailah Hasanah yaitu maksudnya melenceng mengakali tapi untuk kemaslahatan. Karna apabila membeli barang mewakilkan kepada anggota tanpa ada akad itu tidak maslahat, karena apabila anggota 
tidak jujur dan kabur membawa uang pihak KSPPS BMT PAS tidak bisa menuntut karena belum adanya akad. Sehingga pihak KSPPS BMT PAS tidak mewakilkan melakukan pembelian terlebih dahulu kepada anggota sebelum dilakukannya akad. Ini tidak sesuai dengan Point kesembilan tapi dalam hukumnya masih diperbolehkan.

Dari kesembilan point diatas hanya satu point yang pelaksanaannya tidak sesuai dengan fatwa DSN-MUI nomor 04/DSNMUI/IV/2000 tetapi dapat disimpulkan secara keseluruhan untuk pelaksanaan akad Murabahah di KSPPS BMT PAS sesuai dengan ketentuan yang ada di fatwa DSNMUI dan sesuai berdasarkan prinsip syariah.

\section{Penerapan Akad Ijarah Ultra Mikro di KSPPS BMT PAS}

Salah satu akad yang terdapat pada pembiayaan ultra mikro multijasa adalah akad Ijarah. Menurut fatwa DSN MUI No. 112/DSN-MUI/IX/2017 tentang akad Ijarah, akad Ijarah adalah akad sewa antara mu'jir (pemberi sewa) dengan musta'jir (pihak yang menyewa) atau antara musta'jir (pihak yang menyewa) dengan ajir (pihak yang memberikan jasa) untuk mempertukarkan manfa'ah dan ujrah, baik manfaat barang maupun jasa (Fatwa DSN MUI Nomor 112/DSN-MUI/IX/2017 Tentang Akad Ijarah, 2017).

Salah satu manfaat dari KSPPS BMT PAS yaitu untuk membantu dan melayani kebutuhan anggota yang dibutuhkan. Kebutuhan anggota sangat bermacammacam, salah satunya yang diterima dan dilayani oleh pihak KSPPS BMT PAS adalah kebutuhan anggota dalam membayar dana untuk sekolah anak. Dalam hal ini KSPPS BMT PAS menggunakan akad Ijarah dalam bentuk Wakalah bil Ujrah. Karena, pihak KSPPS BMT PAS hanya menyediakan jasa pembiayaan yang sipatnya jasa untuk kepentingan pembayaran tertentu, salah satunya untuk pembayaran sekolah anak, tidak menyewakan barang tertentu.

Pelaksanaan akad wakalah bil ujrah merupakan salah satu akad yang paling banyak digunakan setelah akad murabahah. Kebanyakan anggota mengajukan pembiayaan untuk keperluan bayaran sekolah anak.

Proses untuk pelaksanaan akad wakalah bil ujrah dimana anggota mengajukan pembiayaan kepada pihak KSPPS BMT PAS untuk melakukan pembayaran keperluan anggota. Dalam hal ini anggota memberikan mandat atau mewakilkan kuasa kepada pihak KSPPS BMT PAS untuk melakukan pembayaran yang dibutuhkan anggota contohnya untuk pembayaran sekolah anak. Kemudian dalam teknis pembayarannya tidak hanya oleh pihak KSPPS BMT PAS saja untuk melakukan pembayaran kepada pihak sekolah, tetapi kebanyakan yang melakukan pembayarannya adalah pihak KSPPS BMT PAS.

Pada dasarnya konsep terjadinya akad wakalah bil ujrah antara lain akad wakalah (wakil) dengan akad Ijarah (sewa menyewa) dan ujrah (upah). Dalam hal ini yang akan dibahas peneliti adalah ujrah yang diterapkan BMT pada akad wakalah bil ujrah. Dimana untuk Ujrah nya telah ditentukn dalam fatwa DSN-MUI nomor 112/DSN-MUI/IX/2017 tentang akad Ijarah dan untuk teknis pelaksanaannya, akad Ijarah ini ditentukan dalam fatwa DSN-MUI nomor 09/DSNMUI/IV/2000 tentang pembiayaan Ijarah.

Oleh karena itu, peneliti membuat penyesuaian terkait pelaksanaan akad Ijarah dan ujrah nya di KSPPS BMT PAS dengan ketentuan fatwa DSN-MUI Nomor 09/DSNMUI/IV/2000 sebagai berikut: 
Tabel 4.2

Ketentuan Pelaksanaan Pembiayaan Ijarah

\begin{tabular}{|c|c|c|c|}
\hline \multirow[t]{2}{*}{ No } & \multirow{2}{*}{$\begin{array}{c}\text { Fatwa DSN-MUI } \\
\text { Nomor 09/DSN-MUI/IV/2000 }\end{array}$} & \multicolumn{2}{|c|}{$\begin{array}{l}\text { Kesesuaian } \\
\text { Syariah }\end{array}$} \\
\hline & & Sesuai & Tidak \\
\hline 1 & $\begin{array}{l}\text { Obyek Ijarah adalah manfaat dari } \\
\text { penggunaan barang dan/atau jasa. }\end{array}$ & $\checkmark$ & \\
\hline 2 & $\begin{array}{l}\text { Manfaat barang atau jasa harus bisa } \\
\text { dinilai dan dapat dilaksanakan } \\
\text { dalam kontrak. }\end{array}$ & $\checkmark$ & \\
\hline 3 & $\begin{array}{l}\text { Manfaat barang atau jasa harus } \\
\text { yang bersifat dibolehkan (tidak } \\
\text { diharamkan). }\end{array}$ & $\checkmark$ & \\
\hline 4 & $\begin{array}{l}\text { Kesanggupan memnuhi manfaat } \\
\text { harus nyata dan sesuai dengan } \\
\text { syariah. }\end{array}$ & $\checkmark$ & \\
\hline 5 & $\begin{array}{lr}\text { Manfaat harus dikenali secara } \\
\text { spesifik sedemikian rupa untuk } \\
\text { menghilangkan } & \text { jahalah } \\
\text { (ketidaktahuan) yang } & \text { akan } \\
\text { mengakibatkan sengketa. } & \\
\end{array}$ & $\checkmark$ & \\
\hline 6 & $\begin{array}{l}\text { Spesifikasi manfaat harus } \\
\text { dinyatakan dengan jelas, termasuk } \\
\text { jangka waktunya. Bisa juga } \\
\text { dikenali dengan spesifikasi atau } \\
\text { identifikasi fisik. }\end{array}$ & $\checkmark$ & \\
\hline 7 & $\begin{array}{l}\text { Sewa atau upah adalah sesuatu } \\
\text { yang dijanjikan dan dibayar } \\
\text { nasabah kepada } \\
\text { Keuangan Sembaga } \\
\text { pembayaran manfaat. Sesuatu yang } \\
\text { dapat dijadikan harga dalam jual } \\
\text { beli dapat pula dijadikan sewa atau } \\
\text { upah dalam Ijarah. }\end{array}$ & $\checkmark$ & \\
\hline 8 & $\begin{array}{l}\text { Pembayaran sewa atau upah boleh } \\
\text { berbentuk jasa (manfaat lain) dari } \\
\text { jenis yang sama dengan obyek } \\
\text { kontrak. }\end{array}$ & & $\checkmark$ \\
\hline 9 & $\begin{array}{l}\text { Kelenturan (flexibility) dalam } \\
\text { menentukan sewa atau upah dapat } \\
\text { diwujudkan dalam ukuran waktu, } \\
\text { tempat dan jarak. }\end{array}$ & $\checkmark$ & \\
\hline
\end{tabular}

Sumber: Diolah oleh Peneliti

Berdasarkan point pertama, obyek Ijarah adalah manfaat dari penggunaan barang dan/atau jasa. Setelah melakukan wawancara dengan Manager KSPPS BMT PAS, dalam pelaksanaan akad Ijarah di KSPPS BMT PAS yaitu dalam bentuk akad Wakalah bil Ujrah. Dalam hal ini yang ditawarkan pihak KSPPS BMT PAS adalah pembiayaan yang dilakukan untuk keperluan jasa yang diperlukan anggota. Menurut peneliti ini sudah sesuai dengan ketentuan yang ada di point pertama.

Selanjutnya point kedua, manfaat barang atau jasa harus bisa dinilai dan dapat dilaksanakan dalam kontrak. Dalam hal ini kebanyakan yang dilakukan di KSPPS BMT PAS adalah pembiayaan untuk melakukan pembayaran biaya sekolah anak, dan selalu digunakan lembar perjanjian akad ketika berlangsungnya akad. Sehingga point kedua sudah sesuai dalam pelaksanaannya.

Kemudian point ketiga, manfaat barang atau jasa harus yang bersifat dibolehkan (tidak diharamkan). Dalam pelaksanaan akad Ijarah di KSPPS BMT PAS kebanyakan pelaksanaan akad Ijarah diperuntukan untuk pembiayaan sekolah anak. Sehingga menurut peneliti hal tersebut tidak diharamkan dalam syariat Islam, dan sesuai dengan syariah.

Selanjutnya point keempat kesanggupan memenuhi manfaat harus nyata dan sesuai dengan syariah. Setiap akan melakukan transaksi akad Wakalah bil Ujrah pihak KSPPS BMT PAS selalu melakukan survey dan analis kredit terlebih dahulu. Hal ini dilakukan untuk melihat kesiapan dan kesanggupan baik dari pihak KSPPS BMT PAS ataupun pihak anggota untuk melakukan pembiayaan dan akad tersebut. Apabila kedua belah pihak sudah sanggup dan siap untuk melakukan pembiayaan tersebut maka dilakukan pelaksanaan akad sesuai dengan ketentuan syariah. Menurut peneliti sudah sesuai dengan point keempat, karena adanya survey dan analisis kredit untuk mengetahui kesiapan dan kesanggupan kedua belah pihak sebelum dilakukannya akad.

Lalu point kelima, manfaat harus dikenali secara spesifik sedemikian rupa untuk menghilangkan jahalah (ketidaktahuan) yang akan mengakibatkan sengketa. Ketika akan mengajukan pembiayaan ke KSPPS BMT PAS anggota menjelaskan kebutuhannya secara jelas dan spesifik, kemudian pihak 
KSPPS BMT PAS melakukan analisis dan memastikan mengenai kebutuhan anggota tersebut. Jika kegunaannya untuk bayaran sekolah anak, maka pihak KSPPS BMT PAS datang langsung ke sekolah untuk memastikan jumlah yang diperlukannya. Sehingga semuanya dilakukan secara jelas, hal ini sudah sesuai dengan point kelima.

Selanjutnya point keenam, spesifikasi manfaat harus dinyatakan dengan jelas, termasuk jangka waktunya. Bisa juga dikenali dengan spesifikasi atau identifikasi fisik. Setelah pihak KSPPS BMT PAS memastikan dan menganalisis kebutuhan anggota, maka pihak KSPPS BMT PAS melakukan kesepakatan mengenai akad dan jangka waktu untuk pengembaliannya. Sehingga peneliti berpendapat pelaksanaannya sudah sesuai dengan point keenam.

Berikutnya point ketujuh, sewa atau upah adalah sesuatu yang dijanjikan dan dibayar nasabah kepada Lembaga Keuangan Syariah sebagai pembayaran manfaat. Sesuatu yang dapat dijadikan harga dalam jual beli dapat pula dijadikan sewa atau upah dalam Ijarah. Dalam hal ini pihak KSPPS BMT PAS sebelum melakukan pencairan melakukan kesepakatan terlebih dahulu sebelum melakukan akad. Setelah dilakukan analisis krredit terhadap anggota, pihak KSPPS BMT PAS menyampaikan terkatit ujrah yang diterapkan. Apabila anggota merasa keberatan dengan upah yang diterapkan, maka bisa dimusyawarahkan sampai terjadi kesepakatan antara kedua belah pihak. Setelah terjadi kesepakatan bersama, maka dilakukan akad. Sehingga dalam pelaksanaannya ini, menurut peneliti sudah sesuai dengan point ketujuh.

Kemudian point kedelapan pembayaran sewa atau upah boleh berbentuk jasa (manfaat lain) dari jenis yang sama dengan obyek kontrak. Pelaksanaan akad Wakalah bil Ujrah yang dilakukan di KSPPS BMT PAS yaitu
Wakalah yang termasuk dalam akad Tijarah. Dimana akad Tijarah ini bersifat provit transation oriented yaitu transaksi yang bertujuan untuk mencari keuntungan yang bersifat komersial. Maka dalam pembayaran Ujrah yang dilakukan di KSPPS BMT PAS dari hasil observasi dan wawancara, berbentuk provit tidak berbentuk jasa lain. Sehinga, menurut peneliti yang dilaksanakan di KSPPS BMT PAS tidak sesuai dengan point kedelapan, tapi masih sesuai dengan syariah.

Point yang terakhir yaitu kelenturan (flexibility) dalam menentukan sewa atau upah dapat diwujudkan dalam ukuran waktu, tempat dan jarak. Pelaksanaan ketentuan ujrah atau upah yang dilakukan pihak KSPPS BMT PAS selalu disesuaikan dengan kesepakatan dan kesanggupan anggota dalam melakukan pembayaran serta waktu pembayarannya. Dalam hal ini, sudah sesuai dengan ketentuan yang ada di point yang terakhir.

Selanjutnya untuk ketentuan pelaksanaan Ujrah yang dilakukan di KSPPS BMT PAS dengan ketentuan fatwa DSN-MUI Nomor 112/DSN-MUI/IX/2017 sebagai berikut:

Tabel 4.3

Ketentuan Pelaksanaan Ujrah

\begin{tabular}{|c|c|c|c|}
\hline \multirow[t]{2}{*}{ No } & \multirow{2}{*}{$\begin{array}{c}\text { Fatwa DSN-MUI } \\
\text { Nomor 112/DSN-MUI/IX/2017 }\end{array}$} & \multicolumn{2}{|c|}{$\begin{array}{l}\text { Kesesuaian } \\
\text { Syariah }\end{array}$} \\
\hline & & Sesuai & Tidak \\
\hline 1 & $\begin{array}{l}\text { Ujrah boleh berupa uang, manfaat } \\
\text { barang, jasa, atau barang yang } \\
\text { boleh dimanfaatkan menurut } \\
\text { syariah (mutaqawwam) dan } \\
\text { peraturan perundang-undangan } \\
\text { yang berlaku. }\end{array}$ & $\checkmark$ & \\
\hline 2 & $\begin{array}{l}\text { Kuantitas dan/atau kualitas Ujrah } \\
\text { harus jelas, baik berupa angka } \\
\text { nominai, prosentase tertentu, atau } \\
\text { rumus yang disepakati dan } \\
\text { diketahui oleh para pihak yang } \\
\text { melakukan akad. }\end{array}$ & $\checkmark$ & \\
\hline 3 & $\begin{array}{l}\text { Ujrah boleh dibayar secara tunai, } \\
\text { bertahap/angsur, dan tangguh } \\
\text { berdasarkan kesepakatan sesuai } \\
\text { dengan syariah dan/atau peraturan } \\
\text { perundang-undangan } \\
\text { berlaku. }\end{array}$ & $\checkmark$ & \\
\hline
\end{tabular}




\begin{tabular}{|c|c|c|c|}
\hline \multirow{2}{*}{ No } & \multicolumn{1}{|c|}{ Fatwa DSN-MUI } & \multicolumn{2}{|c|}{$\begin{array}{c}\text { Kesesuaian } \\
\text { Syariah }\end{array}$} \\
\cline { 3 - 4 } & Nomor 112/DSN-MUI/IX/2017 & Sesuai & Tidak \\
\hline \multirow{2}{*}{4} & $\begin{array}{l}\text { Ujrah yang telah disepakati boleh } \\
\text { ditinjau-ulang atas manfaat yang } \\
\text { belum diterima oleh Musta'jir } \\
\text { sesuai kesepakatan. }\end{array}$ & $\checkmark$ & \\
\hline
\end{tabular}

Sumber: Diolah oleh Peneliti

Berdasarkan point pertama, Ujrah boleh berupa uang, manfaat barang, jasa, atau barang yang boleh dimanfaatkan menurut syariah (mutaqawwam) dan peraturan perundang-undangan yang berlaku. Pelaksanaan Ujrah yang diterapkan di KSPPS BMT PAS dari hasil observasi dan wawancara yaitu berupa profit uang yang merupakan keuntungan yang didapatkan dari anggota setelah melakukan pembiayaan atas kebutuhan anggota. Ini sudah sesuai dan termasuk dalam point yang pertama.

Kemudian point kedua, kuantitas dan/atau kualitas Ujrah harus jelas, baik berupa angka nominal, presentase tertentu, atau rumus yang disepakati dan diketahui oleh para pihak yang melakukan akad. Dalam setiap pelaksanaan akad di KSPPS BMT PAS, pihak KSPPS BMT PAS selalu melakukan kesepakatan terlebih dahulu sebelum berlangsungnya akad. Kesepakatan tersebut mengenai harga, jangka waktu angsuran, jumlah angsuran dan margin atau keuntungan. Dalam akad Wakalah bil Ujrah sendiri untuk jumlah ujrah dilakukan kesepakatan terlebih dahulu dengan anggota. Apabila anggota merasa keberatan, bisa dilakukan negosiasi kembali dengan pihak KSPPS BMT PAS sampai terjadinya kesepakatan bersama. Sehingga menurut peneliti sudah sesuai dengan point kedua ini.

Selanjutnya point ketiga, Ujrah boleh dibayar secara tunai, bertahap/ angsur, dan tangguh berdasarkan kesepakatan sesuai dengan syariah dan/atau peraturan perundang-undangan yang berlaku. Pelaksanaan Ujrah di KSPPS BMT PAS dilakukan dengan cara bertahap/angsur yang sudah disatukan dengan harga pokok. Jadi setelah dilakukannya kesepakatan dan akad, jumlah nilai angsuran sudah termasuk dengan jumlah Ujrah nya. Hal ini, sudah sesuai dan termasuk kedalam point ketiga.

Dan yang terakhir point keempat, Ujrah yang telah disepakati boleh ditinjau-ulang atas manfaat yang belum diterima oleh Musta'jir sesuai kesepakatan. Dalam pelaksanaan kesepakatan yang dilakukan oleh pihak KSPPS BMT PAS apabila anggota merasa keberatan, maka pihak KSPPS BMT PAS membolehkan untuk dilakukan negosiasi sehingga terjadi kesepakatan dan tidak ada pihak yang merasa diberatkan. Menurut peneliti sudah sesuai dengan point ke empat.

Dari kesembilan point pelaksanaan akad Ijarah yang terdapat dalam fatwa DSN-MUI nomor 09/DSN-MUI/IV/2000 tentang pembiayaan Ijarah terdapat satu point yang tidak sesuai pelaksanaannya di KSPPS BMT PAS, tetapi masih sesuai dengan syariah. Kemudian, untuk pelaksanaan Ujrah yang terdapat dalam fatwa DSN-MUI nomor 112/DSN-MUI/IX/2017 tentang akad Ijarah sudah sesuai pelaksanaannya dengan yang dilakukan oleh KSPPS BMT PAS. Sehingga dapat disimpulkan pelaksanaan akad Ijarah di KSPPS BMT PAS sudah sesuai dengan syariah.

\section{Penerapan Pembiayaan Ultra Mikro di} KSPPS BMT PAS Berdasarkan Prinsip Syariah

Menurut fatwa DSN-MUI nomor 119/DSN-MUI/II/2018 pembiayaan ultra mikro adalah pembiayaan yang diberikan Lembaga Keuangan Syariah kepada anggota yang membutuhkan sekumpulan barang dan atau jasa yang nilainya sangat kecil (ultra mikro) dan beragam jenisnya (Fatwa DSNMUI Nomor 119/DSN-MUI/II/2018 Tentang Pembiayaan Ultra MIkro Berdasarkan Prinsip Syariah, 2018). 
Setelah dilakukan observasi dan wawancara dengan pihak KSPPS BMT PAS untuk pelaksanaan pembiayaan ultra mikro di KSPPS BMT PAS dilakukan berdasarkan fatwa DSN-MUI nomor 119/DSNMUI/II/2018 tentang pembiayaan ultra mikro berdasarkan prinsip syariah. Di BMT sendiri jumlah nominal untuk pembiayaan ultra mikro maksimal yaitu Rp 5 juta tidak lebih dan paling kecil Rp 500 ribu bahkan ada yang sampai mengajukan Rp 300 ribu. Mekanisme pelaksanaannya sendiri dibuat lebih mudah tanpa mempersulit anggota yang mengajukan, yaitu pertama anggota mengajukan pembiayaan ke BMT dengan syarat menyerahkan fotocopy Kartu Tanda Penduduk (KTP) dan harus menjadi anggota terlebih dahulu, kedua dilakukan survey oleh pihak KSPPS BMT PAS kepada anggota yang mengajukan pembiayaan. Setelah itu, dilakukan survey jika di setujui pengajuannya maka dilakukan kesepakatan terlebih dahulu mengenai margin dan jangka waktu untuk angsurannya. Setelah disepakati, maka dilakukan akad dengan anggota langsung dan pencairan pinjamannya bisa diantar langsung ke anggota oleh pihak KSPPS BMT PAS atau anggota mengambil ke kantor.

Dari hasil observasi serta wawancara yang telah dilakukan di KSPPS BMT PAS mengenai pembiayaan ultra mikro berdasarkan fatwa DSN-MUI No. 119/DSNMUI/IX/2018 sebagai berikut:

Tabel 4.4

Penerapan Pembiayaan Ultra Mikro

\begin{tabular}{|c|c|c|c|}
\hline \multirow{2}{*}{ No } & \multicolumn{1}{|c|}{ Fatwa DSN-MUI } & \multicolumn{2}{|c|}{$\begin{array}{c}\text { Kesesuaian } \\
\text { Syariah }\end{array}$} \\
\cline { 3 - 4 } & Nomor 119/DSN-MUI/II/2018 & Sesuai & Tidak \\
\hline \multirow{8}{*}{1} & $\begin{array}{l}\text { Jika menggunakan akad jual-beli } \\
\text { murabahah, maka wajib tunduk } \\
\text { dan patuh pada ketentuan } \\
\text { (dhawabith) dan batasan (hudud) } \\
\text { yang terdapat dalam fatwa DSN- }\end{array}$ & $\checkmark$ & \\
$\begin{array}{l}\text { MUI nomor 04/DSNMUI/IV/2000 } \\
\text { tentang Murabahah. }\end{array}$ & $\checkmark$ & \\
\hline 2 & $\begin{array}{l}\text { Jika akad yang digunakan adalah } \\
\text { akad Ijarah, maka wajib tunduk } \\
\text { dan patuh pada ketentuan }\end{array}$ & $\checkmark$ & \\
\hline
\end{tabular}

\begin{tabular}{|c|c|c|c|}
\hline \multirow[t]{2}{*}{ No } & \multirow{2}{*}{$\begin{array}{c}\text { Fatwa DSN-MUI } \\
\text { Nomor 119/DSN-MUI/II/2018 }\end{array}$} & \multicolumn{2}{|c|}{$\begin{array}{c}\text { Kesesuaian } \\
\text { Syariah }\end{array}$} \\
\hline & & Sesuai & Tidak \\
\hline & $\begin{array}{l}\text { (dhawobith) dan batasan (hudud) } \\
\text { yang terdapat dalam fatwa DSN- } \\
\text { MUI nomor 09/DSN- } \\
\text { MUI/IV/2000 tentang Pembiayaan } \\
\text { ljarah dan fatwa DSN-MUI nomor } \\
\text { 112/DSN-MUI/IX/2017 tentang } \\
\text { Akad Ijarah. }\end{array}$ & & \\
\hline 3 & $\begin{array}{l}\text { Dalam hal pelaksanaan akad } \\
\text { terutama akad jual beli dan sewa } \\
\text { menyewa } \\
\text { (Ijarah) menimbulkan kesulitan, } \\
\text { untuk memperrnudah transaksi, } \\
\text { para pihak boleh: } \\
\text { a. menggunakan Akad } \\
\text { Pokok dan Akad Wakalah } \\
\text { sebagai Akad Pelengkap. atau } \\
\text { b. menggunakan bentuk Akad } \\
\text { Mu'allaq pada Akad Pokok } \\
\text { ditambah Akad Wakalah } \\
\text { sebagai Akad Pelengkap. }\end{array}$ & $\checkmark$ & \\
\hline 4 & $\begin{array}{l}\text { Akad mu'allaq yang objeknya } \\
\text { barang maupun jasa harus jelas } \\
\text { dan terukur spesifikasinya } \\
\text { (kuantitas dan kualitas) sesuai } \\
\text { dengan kebiasaan usaha antar para } \\
\text { pelaku bisnis ('urf tijari): }\end{array}$ & $\checkmark$ & \\
\hline 5 & $\begin{array}{l}\text { Akad Mu'allaq berlaku efektif } \\
\text { pada saat Anggota sebagai wakil } \\
\text { melaksanakan objek wakalah. }\end{array}$ & $\checkmark$ & \\
\hline 6 & $\begin{array}{lll}\text { Dalam pelaksanaan } & \text { Akad } \\
\text { Mu'allaq pada anggota } & \text { wajib } \\
\text { melaporkan pelaksanakan } & \text { Akad } \\
\text { Wakalah berikut bukti yang } \\
\text { relevan sesuai dengan 'urf paling } \\
\text { lama 15 hari setelah pelaksanaan. }\end{array}$ & $\checkmark$ & \\
\hline
\end{tabular}

Sumber: Diolah oleh Peneliti

Berdasarkan Point pertama, jika menggunakan akad jual-beli murabahah, maka wajib tunduk dan patuh pada ketentuan (dhawabith) dan batasan (hudud) yang terdapat dalam fatwa DSN-MUI nomor 04/DSNMUI/IV/2000 tentang Murabahah. Menurut peneliti sudah sesuai dengan syariah, karena pada tabel 4.5 sudah dijelaskan pelaksanaan akad murabahah di KSPPS BMT PAS sudah sesuai dengan fatwa DSNMUI nomor 04/DSN-MUI/IV/2000

Kemudian Point kedua, jika akad yang digunakan adalah akad Ijarah, maka wajib tunduk dan patuh pada ketentuan (dhawobith) dan batasan (hudud) yang terdapat dalam fatwa DSN-MUI nomor 09/DSN-

EKSISBANK (Ekonomi Syariah dan Bisnis Perbankan), Volume 4, Nomor 2, Desember 2020 http://journal.sties-purwakarta.ac.id/index.php/EKSISBANK/ 
MUI/IV/2000 tentang Pembiayaan ljarah dan fatwa DSN-MUI nomor 112/DSNMUI/IX/2017 tentang Akad Ijarah.sudah sesuai dengan syriah. Karena pada tabel 4.6 dan tabel 4.7 sudah dijelaskan dan sudah sesuai dengan fatwa DSN-MUI nomor 09/DSN-MUI/IV/2000 tentang pembiayaan Ijarah dan fatwa DSN-MUI nomor 112/DSNMUI/IX/2017 tentang akad Ijarah.

Selanjutnya, point ketiga Dalam hal pelaksanaan akad terutama akad jual beli dan sewa menyewa (Ijarah) menimbulkan kesulitan, untuk memperrnudah transaksi, para pihak boleh:

a. Menggunakan Akad Pokok dan Akad Wakalah sebagai Akad Pelengkap; atau

b. menggunakan bentuk Akad Mu'allaq pada Akad Pokok ditambah Akad Wakalah sebagai Akad Pelengkap sesuai dengan syariah,

Dalam pelaksanaan pembiayaan ultra mikro di KSPPS BMT PAS apabila mengalami kesulitan dalam pelaksanaannya, maka pihak KSPPS BMT PAS selalu menggunakan akad Wakalah sebagai akad pelengkap. untuk mempermudah anggota dalam pelakpembiayaan. Hal ini dinilai peneliti sudah sesuai dengan point ketiga.

Berikutnya Point keempat, akad mu'allaq yang objeknya barang maupun jasa harus jelas dan terukur spesifikasinya (kuantitas dan kualitas) sesuai dengan kebiasaan usaha antar para pelaku bisnis ('urf tijari). Dari hasil data di lapangan dalam pelaksanaan pembiayaan ultra mikro mikro, pihak KSPPS BMT PAS selalu melakukan analis kredit terlebih dahulu terhadap kebutuhan anggota yang mengajukan pembiayaan. Untuk mengukur lebih dalam kebutuhan dan kesanggupan anggota dalam membayar angsurannya. Setelah itu, pihak KSPPS BMT PAS melakukan survey kepada angggota untuk mengetahui lebih jelas mengenai obyek barang atau jasa yang diajukan oleh anggota tersebut, agar tidak terjadi kesalahan dalam proses pelaksanaan pembiayaannya. Sehingga menurut peneliti sesuai dengan yang ada di point keempat.

Lalu, pada Point kelima akad Mu'allaq berlaku efektif pada saat Anggota sebagai wakil melaksanakan objek wakalah. Dari hasil data yang ditemukan di lapangan, dalam setiap pelaksanaan pembiayaan ultra mikro yang sipatnya harus dilakukan akad Mu'allaq atau akad Wakalah sebagai akad pelengkap, KSPPS BMT PAS selalu mewakilkan kepada anggota yang mengajukannya. Karena yang lebih paham dan lebih mengerti untuk kebutuhannya adalah anggota itu sendiri. Sehingga agar lebih efektif dalam pelaksanaan akadnya.dalam hal ini menurut peneliti sudah sesuai dengan point yang kelima.

Dan yang terakhir, Point keenam dalam pelaksanaan Akad Mu'allaq pada anggota wajib melaporkan pelaksanakan Akad Wakalah berikut bukti yang relevan sesuai dengan 'urf paling lama 15 hari setelah pelaksanaan. Setiap setelah melaksanaan akad mu'allaq atau wakalah untuk membelikan kebutuhannya, anggota tersebut wajib melaporkan pelaksanaan akad wakalah berikut memberikan bukti yang relavan seperti kuitansi kepada KSPPS BMT PAS maksimal 5 hari kerja. Hal ini sudah sesuai dengan point yang keenam, tidak melebihi batas yang telah ditentukan.

Dari uraian ke enam point di atas bisa disimpulkan bahwa pelaksanaan pembiayaan ultra mikro di KSPPS BMT PAS sudah sesuai dengan fatwa DSN-MUI nomor 119/DSNMUI/II/2018 tentang pembiayaan ultra mikro berdasarkan prinsip syariah prinsip syariah.

\section{PENUTUP}

Berdasarkan hasil penelitian mengenai "Implementasi Pembiayaan Ultra MIkro 
Berdasaran Prinsip Syariah di KSPPS BMT Purwakarta Amanah Sejahtera (PAS).” yang dilakukan melalui observasi, wawancara, dokumentasi serta. Peneliti mengambil kesimpulan sebagai berikut:

1. Model pembiayaan ultra mikro yang dilakukan di KSPPS BMT PAS adalah pembiayaan yang dilakukan dengan batas maksimal pembiayaan Rp 5 juta. Syarat untuk melakukan pembiayaan ultra mikro di KSPPS BMT PAS yaitu harus menjadi anggota KSPPS BMT PAS terlebih dahulu dan aktif dalam membayar simpanan wajib. Kemudian baru bisa melakukan pembiayaan ultra mikro. Di KSPPS BMT PAS produk akad ultra mikro yang digunakan adalah akad Murabahah pada pembiayaan ultra mikro multibarang dan akad Ijarah dalam bentuk akad Wakalah bil Ujrah pada pembiayaan ultra mikro multijasa.

2. Implementasi pembiayaan ultra mikro di KSPPS BMT PAS sudah sesuai dengan fatwa DSN-MUI nomor 119/DSNMUI/II/2018 tentang pembiayaan ultra mikro berdasarkan prinsip syariah. Karena, dalam setiap pelaksanaan akad pembiayaan ultra mikro yang ada di KSPPS BMT sudah sesuai dengan fatwa DSN-MUI, yaitu dalam pembiayaan ultra mikro multibarang pelaksanaannya sudah sesuai dengan fatwa DSN-MUI nomor 04/DSN-MUI/IV/2000 tentang Murabahah. Serta untuk pembiayaan ultra mikro multijasa sudah sesuai dengan fatwa DSN-MUI nomor 09/DSNMUI/IV/2000 tentang pembiayaan Ijarah dan fatwa DSN-MUI nomor 112/DSNMUI/IX/2017 tentang akad Ijarah.

\section{B. Saran}

Setelah paparan kesimpulan penelitian di atas, maka ada beberapa saran dari peneliti untuk KSPPS BMT PAS. Berikut ini adalah saran saran dari peneliti sebagai berikut:

1) Bagi pihak KSPPS BMT PAS agar lebih dipertegas lagi mengenai syarat untuk melakukan pengajuan pembiayaan selain hanya fotocopy KTP saja. Tetapi, baiknya ditambahkan juga dengan persyaratan lainnya berupa kartu kelurga (KK) fotocopy slip gajih bagi anggota yang bekerja di suatu Perusahaan atau Lembaga Pemerintahan.

2) Dalam proses pelaksanaan pembayaran angsuran, alangkah baiknya dibikin suatu aturan yang tegas apabila ada anggota yang telat atau tidak mau bayar angsuran, agar anggota yang melakukan pembiayaan lebih memperhatikan lagi mengenai kewajiban dalam membayar angsurannya..

\section{Rekomendasi}

Berdasarkan kesimpulan yang telah dipaparkan, maka peneliti mengajukan rekomendasi yang dipandang berguna bagi penelitian selanjutnya dan bagi pihak KSPPS BMT PAS maupun anggota.

1) Hasil penelitian menunjukan bahwa implementasi Pembiayaan ultra mikro di KSPPS BMT PAS sudah sesuai dengan prinsip syariah, bagi pihak KSPPS BMT PAS diharapkan agar tetap menjalankan mekanisme tersebut dengan istiqomah. Juga para anggota agar bisa lebih displin lagi dalam hal membayar angsuran agar hubungan lembaga dan anggota bisa lebih baik lagi

2) Untuk peneliti selanjutnya, peneliti mengharapkan adanya kajian yang lebih mendalam dalam melakukan penelitian khususnya mengenai implementasi pembiayaan ultra mikro karena dinilai masih terbilang baru mengenai kebijakan dan peraturan mengenai pembiayaan ultra mikro. Sehingga tidak menutup kemungkinan dalam pelaksanaannya pasti 
akan terdapat hal-hal yang baru dan beragam yang perlu diteliti lebih dalam lagi.

\section{DAFTAR PUSTAKA}

Cahyono, E. A. (2019). Badan Amil Zakat Nasional (BAZNAS) Kabupaten Bojonegoro bekerjasama dengan PD Bank Perkreditan Rakyat (BPR) Bojonegoro memberikan bantuan modal usaha melalui pembiayaan usaha super mikro dengan prinsip syariah kepada masyarakat dari keluarga tidak mampu y. In AL MAQASHIDI (Vol. 2, Issue 1). http://ejournal.sunan-

giri.ac.id/index.php/ALMAQASHIDI/ar ticle/view/187

Fatwa DSN-MUI Nomor 111/DSNMUI/IX/2017 Tentang Akad Jual Beli Murabahah, Pub. L. No. 111/DSNMUI/IX/2017 (2017).

Fatwa DSN MUI Nomor 112/DSNMUI/IX/2017 Tentang Akad Ijarah, Pub. L. No. 112/DSN-MUI/IX/2017 (2017).

Fatwa DSN-MUI nomor 119/DSNMUI/II/2018 tentang Pembiayaan Ultra MIkro Berdasarkan Prinsip Syariah, Pub. L. No. 119/DSN-MUI/II/2018 (2018).

Enang, S. (2010). Al-Qur'an dan Terjemah. PT Madina Raihan Makmur.

Haliding, S. (2019). Kebangkitan Usaha Ultra-Mikro. Https://M.Kontan.Co.Id. https://m.kontan.co.id/news_analisis/keb angkitan-usaha-ultra-mikro?page $=1$

Hidayat, F. (2016). Alternative Sistem Pengawasan Pada Koperasi Simpan Pinjam Dan Pembiayaan Syariah (KSPPS) Dalam Mewujudkan Shariah Compliance. Jurnal Mahkamah : Kajian Ilmu Hukum Dan Hukum Islam, 1(2), 383-407.

https://www.journal.iaimnumetrolampu ng.ac.id/index.php/jm/article/view/47

Kriyantono, \& Rachmat. (2009). Teknik Praktis Riset Komunikasi. Prenada Media Group.

M-Kita. (2019). Tafsir surat An-Nisa ayat 29. M-Kita. https://tafsirweb.com/1561surat-an-nisa-ayat-29.html

Moleong, L. J. (2017). Metodologi Penelitian Kualitatif. Remaja Rosdakarya.

Muttaqin, A. A., \& Hartono, A. R. (2019). Implementasi Penerapan Pembiayaan Ultra Mikro di BMT-UGT Sidogiri. ElBarka: Journal of Islamic Economics and Business, 2(2), 273. https://doi.org/10.21154/elbarka.v2i2.17 60

Nanang (Staff Pembiayaan dan Lapangan KSPPS BMT Purwakarta Amanah). (2019). Hasil Wawancara Tentang Pembiayaan Ultra Mikro di KSPPS Purwakarta Amanah Sejahtera. KSPPS Purwakarta Amanah Sejahtera (PAS).

Nugraha, A. (2019). Hasil Wawancara Tentang Pembiayaan Mikro Kecil di BMT Purwakarta Amanah Sejahtera. KSPPS Purwakarta Amanah Sejahtera (PAS).

Pegadaian. (2019). Pegadaian Salurkan Kredit Umi disaksikan oleh Presiden Jokowi.

Pegadaian. https://www.pegadaian.co.id/berita/detai 1/85/berita-detail.php

Raco, J. R. (2010). Metode Penelitian Kualitatif. PT. Gramedia Widiasarana Indonesia.

Rusydiana, A. S., \& Devi, A. (2013). MENCARI SOLUSI PENGEMBANGAN LEMBAGA KEUANGAN MIKRO SYARIAH DI INDONESIA. Dialog, 36(1), 107-120. https://doi.org/10.47655/dialog.v36i1.85

EKSISBANK (Ekonomi Syariah dan Bisnis Perbankan), Volume 4, Nomor 2, Desember 2020 
Simanjuntak, R. (2018). Pengaruh Kinerja Pembiayaan Mikro Musyarakah dan Mudharabah di Bank Syariah terhadap Sektor Usaha Mikro di Provinsi Jawa Timur. Indonesian Journal of Islamic Economics and Finance, 1(1). http://jurnalpasca.iainjember.ac.id/ejournal/index.php/IJIEF/ar ticle/view/31

Sudjana, K., \& Rizkison. (2020). Peran Baitul Maal Wat Tamwil (BMT) dalam Mewujudkan Ekonomi Syariah yang Kompetitif. Jurnal Ilmiah Ekonomi Islam, $\quad 6(02), \quad$ 185-194. https://doi.org/10.29040/jiei.v6i2.1086

Sugiyono. (2015). Metode Penelitian Kuantitatif, Kualitatif dan $R \& D$. Alfabeta.

Sugiyono. (2016). Metodologi Penelitian
Kuantitatif, Kualitatif dan $R \& D$. Alfabeta.

Sugiyono. (2017). Metode Penelitian Kuantitatif, Kualitatif, dan $R \& D$. Alfabeta.

Surnida, D. (2020). Pembiayaan Ultra Mikro Dalam Peraturan Menteri Keuangan No 95/PMK.05/2018 dan Fatwa Dewan Syariah Nasional No 119/DSNMUI/II/2018. MUAMALATUNA, 12(1), 100.

https://doi.org/10.37035/mua.v12i1.330 9

Yuniarti, V. S. (2016). Ekonomi Mikro Syariah. CV. Pustaka Setia. 